\title{
M(DIUI.
}

IPIRAVRTITERTM

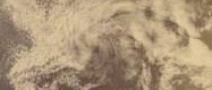
ariOC

GRAFI DASAR

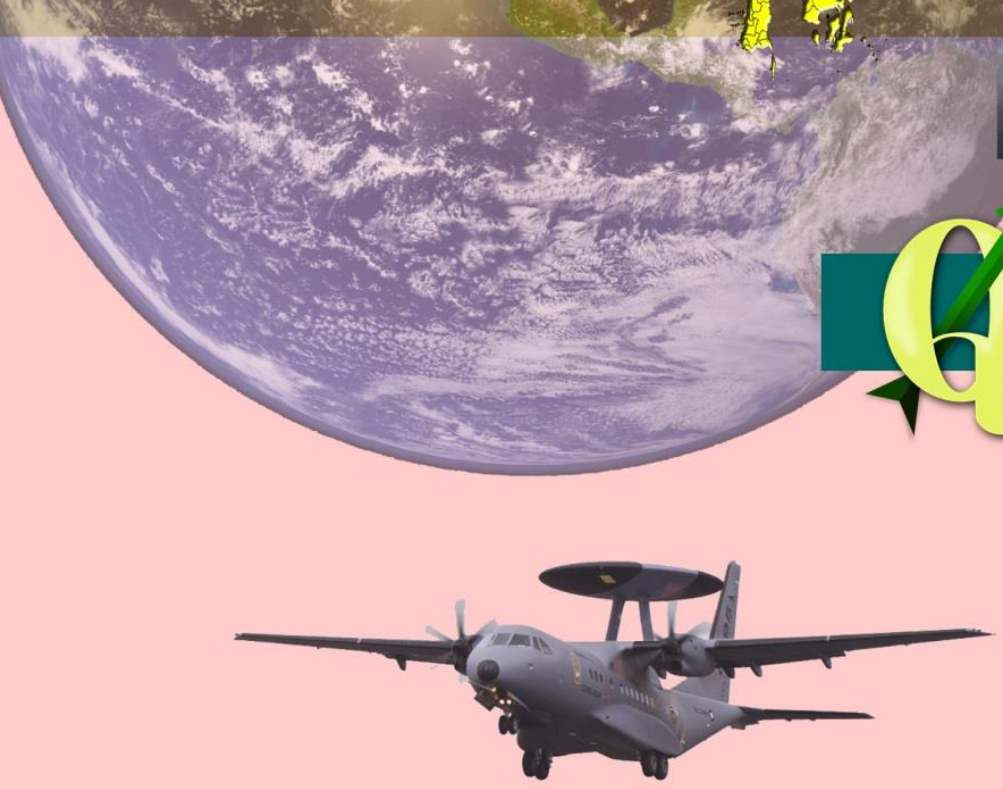

PENYUSUN :

ATTHUR GANI KOTO

menggunakan 


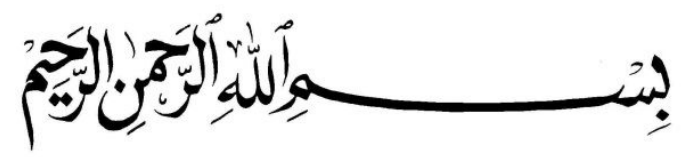

\section{SEKELUMIT KATA}

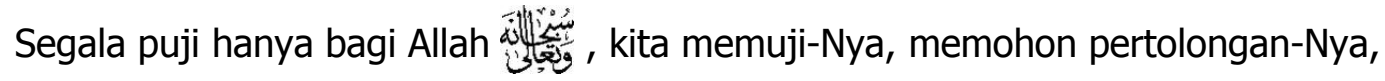
mengharapkan petunjuk-Nya dan ampunan-Nya, serta berlindung kepada Allah dari kejahatan hawa

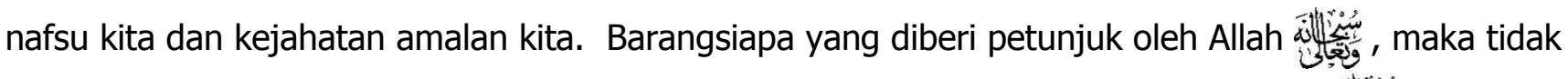
ada satupun yang dapat menyesatkannya, sebaliknya siapapun yang disesatkan Allah tidak satupun yang dapat memberi petunjuk kepadanya.

Saya bersaksi tidak ada sesembahan yang haq kecuali Allah satu-satunya, tidak ada sekutu

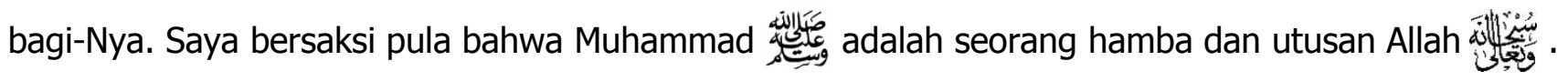

Perangkat lunak pemetaan yang banyak digunakan saat ini (ArcGIS, ArcView, MapInfo, AutoCAD Map) merupakan perangkat lunak yang terus dikembangkan sesuai dengan kebutuhan para pengguna dalam pengaplikasian perangkat lunak tersebut. Berbagai perangkat lunak pemetaan sangat berguna sebagai alat bantu (tool) dalam penyelesaian masalah yang muncul pada berbagai penelitian maupun pengambilan keputusan demi kepentingan-kepentingan tertentu.

Para pengguna perangkat lunak pemetaan sangat diuntungkan dengan semakin banyaknya pilihan perangkat lunak pemetaan yang ada. Perangkat lunak pemetaan tersebut memiliki berbagai macam keunggulan masing-masing. Bahkan bagi kebanyakan orang, memiliki perangkat lunak pemetaan dan mampu mengoperasikan 2 atau lebih perangkat lunak yang digunakan untuk olah data spasial. Hal tersebut dilakukan untuk memudahkan pengguna dalam melakukan pekerjaan terutama yang berkaitan dengan olah data spasial karena ada kalanya suatu perangkat lunak pemetaan tidak memiliki too//fitur yang dibutuhkan sehingga menggunakan perangkat lunak pemetaan lain agar dapat saling melengkapi.

Seiring dengan berkembangnya perangkat lunak pemetaan oleh berbagai pihak (vendor) dan tuntutan akan kegunaan GIS pada aplikasi-aplikasi ilmu pengetahuan yang lebih luas, maka beberapa pihak mulai mengembangkan suatu aplikasi yang lebih murah ataupun gratis namun tetap dapat digunakan untuk melakukan pengolahan data spasial seperti halnya pada perangkat lunak pemetaan yang berlisensi (berbayar). 
Beberapa perangkat lunak pemetaan yang dikembangkan berbasis open source seperti MapWindow, SAGA GIS, DIVA GIS, GRASS GIS, ataupun Quantum GIS dapat beroperasi pada Sistem Operasi Linux, Mac dan Windows. Tidak seperti perangkat lunak pemetaan yang berlisensi lainnya, perangkat lunak ini dapat dikembangkan sendiri sesuai dengan kebutuhan. Selain itu karena perangkat lunak ini merupakan open source dan freeware maka dapat diperoleh dengan gratis dan dapat pula disebarluaskan (sesuai dengan ketentuan pengembangnya) tanpa ada pelanggaran hak cipta.

Meskipun masih dianggap terbatasnya kemampuan-kemampuan perangkat lunak open source tersebut dalam pengolahan data spasial yang lebih lanjut (advanced) dibanding dengan perangkat lunak pemetaan berlisensi, namun perangkat lunak open source sudah lebih dari cukup untuk penyelesaian masalah dalam olah data spasial.

Praktikum Kartografi Dasar dalam lingkungan Universitas Muhammadiyah Gorontalo menggunakan perangkat lunak Quantum GIS (QGIS). Beberapa alasan digunakannya QGIS diantaranya : freeware, dapat beroperasi pada spesifikasi komputer minimal, ringan dan memiliki tool yang cukup lengkap.

Saat modul ini dibuat, QGIS telah mencapai versi 2.2 (Win x86 dan x64) dan dapat diunduh pada alamat : http://www.qgis.org/en/site/forusers/download.html

Semoga dengan adanya modul ini, dapat menambah wawasan dan membantu mahasiswa dalam memahami teori Mata Kuliah Kartografi Dasar dan sebagai salah satu alternatif dalam aplikasi pengolahan data spasial berbasis open source.

$0.59^{\circ} \mathrm{LU} 123.03^{\circ} \mathrm{BT}$, Ramadhan $1435 \mathrm{H}$ 


\section{DAFTARISI}

\section{SEKELUMIT KATA}

I. PENDAHULUAN

1.SEKILASQGIS

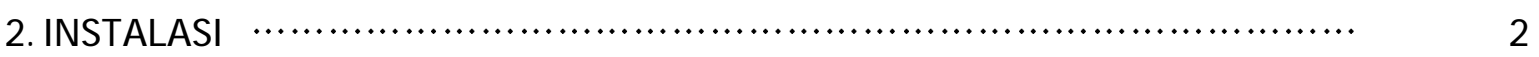

2. PENGENALANTOOLS

3. MENAMPILKAN DATA SPASIAL …............................................ 5

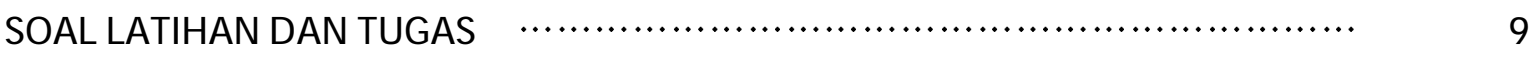

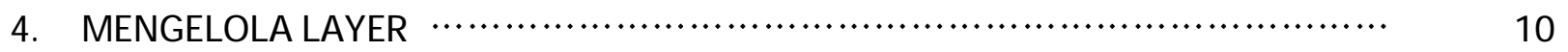

4.1. ON/OFF LAYER

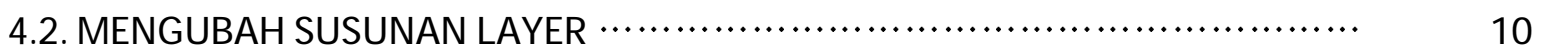

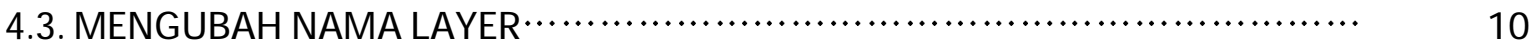

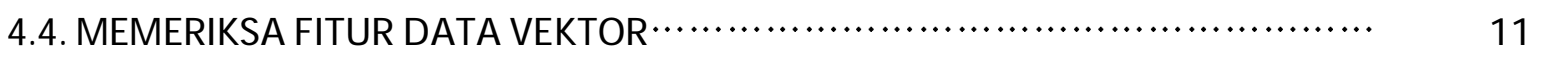

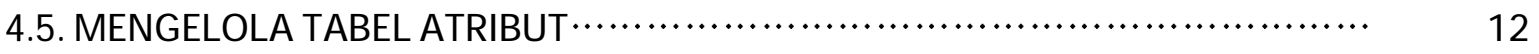

4.6. REPRESENTASI SELECTED FTUR ….......................................

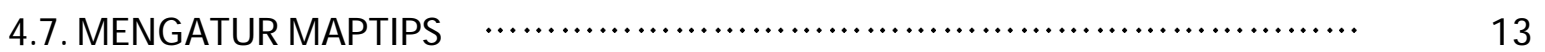

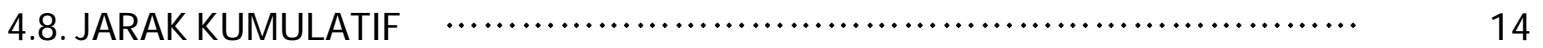

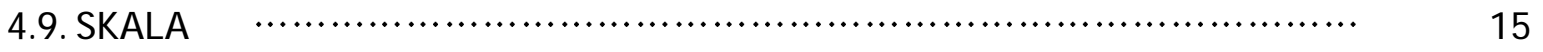

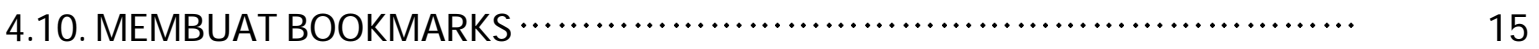

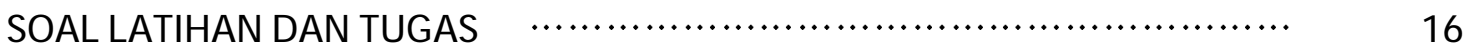

5. GEOREFERENS

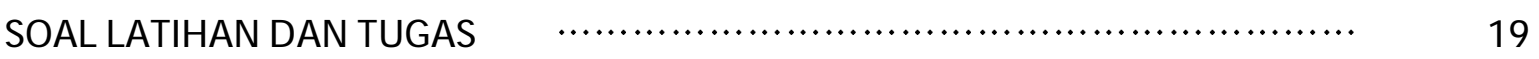

6. PEMBUATAN LAYER …....................................................... 20

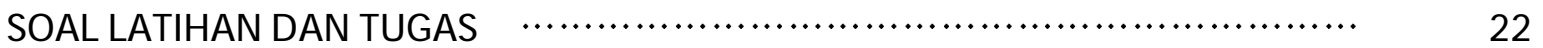

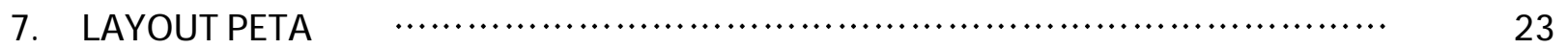

SOAL LATHAN DAN TUGAS

REFERENSI 


\section{PENDAHULUAN}

\section{Sekilas Quantum GIS (QGIS)}

QGIS memiliki kemampuan yang hampir setara dengan beberapa perangkat lunak pemetaan ternama (berlisensi) seperti ArcGIS, ArcView maupun MapInfo. Operasi dasar pada pengolahan data spasial dapat dilakukan dengan menggunakan QGIS yang lebih ringan (tidak memerlukan spesifikasi hardware yang tinggi), murah (tidak memerlukan lisensi karena merupakan open source) dan bahkan dapat dikembangkan lebih lanjut sesuai dengan kepentingan penggunanya.

QGIS dapat digunakan untuk pengolahan data atribut maupun spasial secara umum seperti melakukan overlay layer, menghitung luasan suatu wilayah, memberikan informasi tambahan pada suatu titik, ataupun merancang layout peta. QGIS juga mendukung penggunaan GPS. Pengguna dapat langsung memindahkan data langsung dari GPS ke PC atau sebaliknya. QGIS memiliki fitur-fitur dan fungsi yang dibutuhkan oleh pengguna GIS pada umumnya, oleh karena itu sangat layak untuk dijadikan alternatif perangkat lunak pemetaan dalam berbagai keperluan seperti pemetaan untuk tata ruang ataupun penyusunan peta-peta tematik dalam berbagai penelitian.

QGIS dapat dijalankan pada semua platform Operation System (OS) baik Windows, Mac maupun Linux. QGIS pertama kali dirilis pada tahun 2002. Hingga saat modul ini disusun, QGIS telah mencapai versi 2.2 dengan code name "Valmiera". Lebih lanjut mengenai QGIS dapat dilihat pada alamat http://www.qgis.org/en/site/. Perangkat lunak QGIS versi terbaru untuk berbagai macam platform dapat diunduh secara gratis pada alamat :

http://www.ggis.org/en/site/forusers/download.html

Meskipun tidak ada rilis secara resmi dari pihak pengembang QGIS untuk kebutuhan minimum hardwarenya, namun setidaknya untuk dapat menjalankan QGIS secara lancar spesifikasi yang dibutuhkan adalah sebagai berikut :

$\checkmark$ Processor (AMD/Intel) dengan kecepatan minimal $1,5 \mathrm{GHz}$ (single core)

$\checkmark$ RAM 1 GB

$\checkmark$ Kartu grafis minimal memiliki memori $128 \mathrm{MB}$

$\checkmark$ Ruang kosong pada hardisk 900 MB untuk instalasi 
Meskipun spesifikasi minimum yang dibutuhkan cukup tergolong ringan untuk komputer yang banyak digunakan saat ini, namun tetap saja apabila digunakan untuk pengolahan data spasial yang lebih lanjut, seperti pengolahan citra (data raster) spesifikasi komputer yang lebih tinggi akan memperlancar dalam menjalankan dan mengoperasikan QGIS. Serupa dengan perangkat lunak pemetaan yang lain, QGIS versi terbaru memiliki fitur-fitur yang tentu saja lebih update daripada versi sebelumnya. Pada beberapa versi terbaru, tambahan fitur (yang ditampilkan dalam bentuk icon-icon dalam toolbar) dimunculkan sebagai default dalam tampilannya yang mungkin pada versi sebelumnya tidak terdapat atau harus diaktifkan terlebih. Secara umum fungsi QGIS sebagai pengolah data spasial tidak mengalami perubahan yang signifikan meskipun versi yang digunakan berbeda.

Sampai dengan saat ini, QGIS masih dikembangkan lebih lanjut baik oleh komunitas maupun pengembangnya sendiri. Sebagai alternatif perangkat lunak pemetaan yang dapat melengkapi atau menggantikan perangkat lunak pemetaan yang berlisensi, QGIS sangat perlu diperhatikan oleh pengguna perangkat lunak pemetaan terlebih karena QGIS juga dapat dioperasikan pada platform linux (OS open source).

\section{Instalasi}

Instalasi QGIS pada modul ini menggunakan OS Windows 7 x64. Download QGIS dari http://www.qgis.org/en/site/forusers/download.html kemudian double clik pada installer-nya dan ikuti wizard yang muncul. Tunggu prosesnya, hal ini tergantung pada spesifikasi hardware anda. Kemudian klik "Finish" setelah prosesnya selesai.

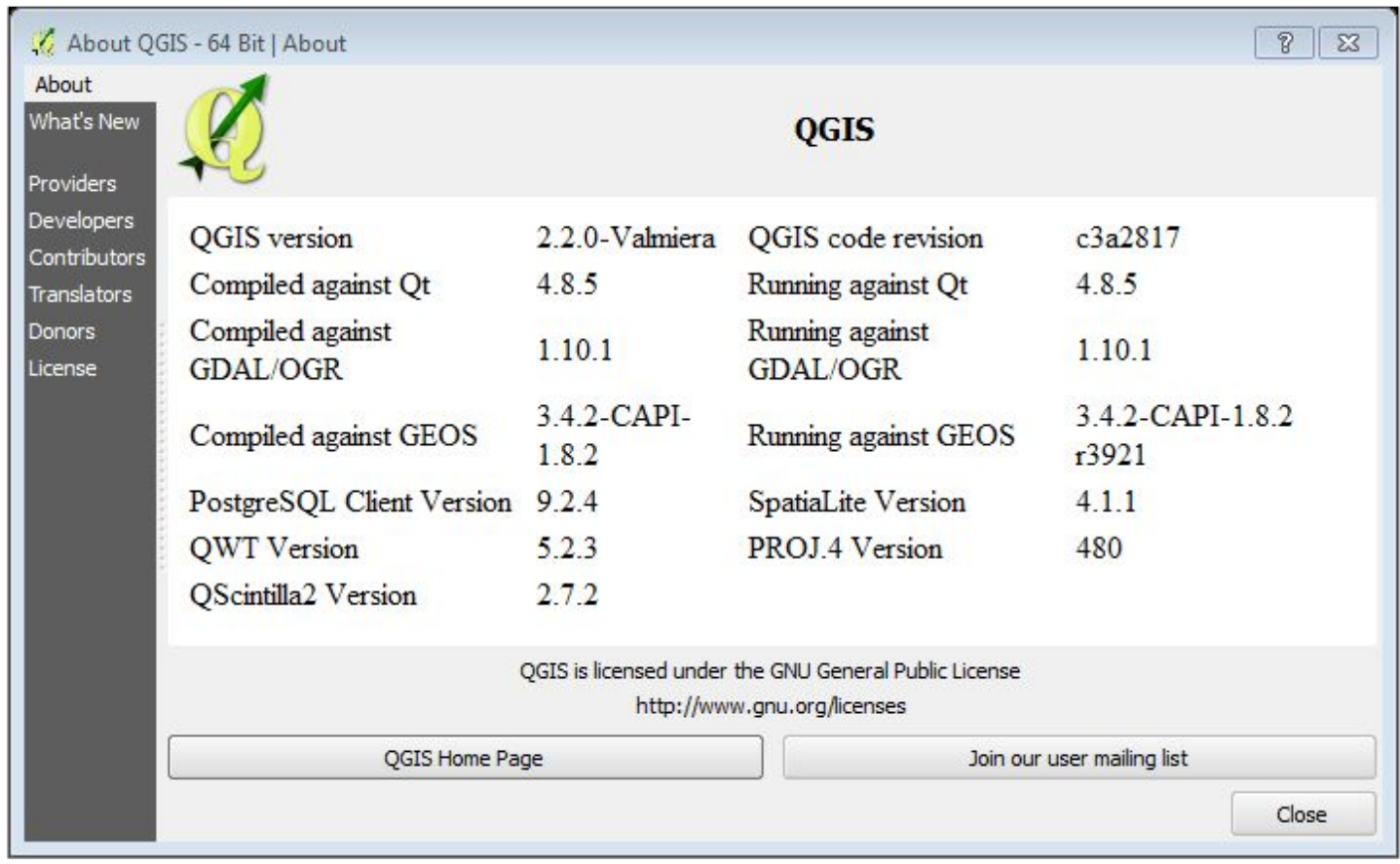




\section{PENGENALAN TOOLS}

- Menu bar

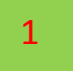

Menu bar menyediakan berbagai macam fitur/fungsi pada Quantum GIS yang akan digunakan untuk pengoperasian lebih lanjut. Sebagian besar fungsi yang ada pada menu bar juga terdapat pada tool bar.

- Tool bar

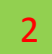

Toolbar terdiri dari deretan gambar (icon) yang menyediakan akses cepat (shortcut) pada fungsifungsi yang sebagian besar sama seperti yang ada pada menu bar.

- Map Legend

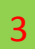

Map Legend menampilkan daftar layer yang sedang dibuka pada project, baik layer yang aktif maupun tidak aktif akan ditampilkan semua. Dapat juga diatur urutan kenampakan layer dengan cara drag and drop pada layer.

- Map View

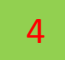

Map View merupakan area dimana layer-layer ditampilkan. Tampilan pada map view tergantung dari layer yang aktif

- Status Bar

Status bar menunjukkan posisi koordinat dimana cursor berada, dengan catatan tampilan yang ada pada jendela Map View sudah memiliki Georeference. Selain menunjukkan posisi, Status Barjuga menunjukkan skala tampilan pada MapView. 


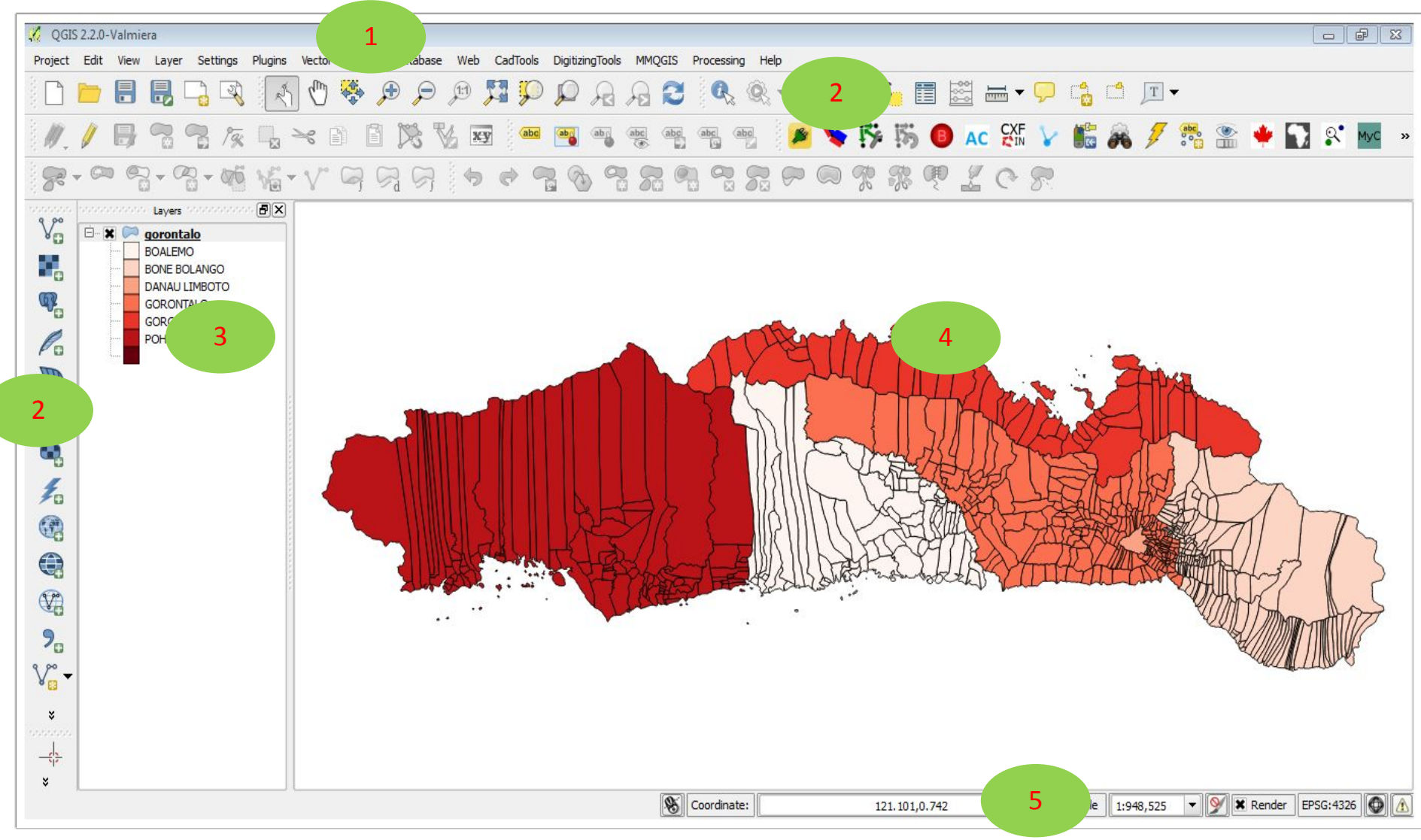

\section{Plugins install}

QGIS menyediakan fitur gratis untuk menambah plugins dengan cara mendownload melalui QGIS plugins repository. Anda dapat mengaksesnya dengan cara klik menu plugins > manage and install plugins...

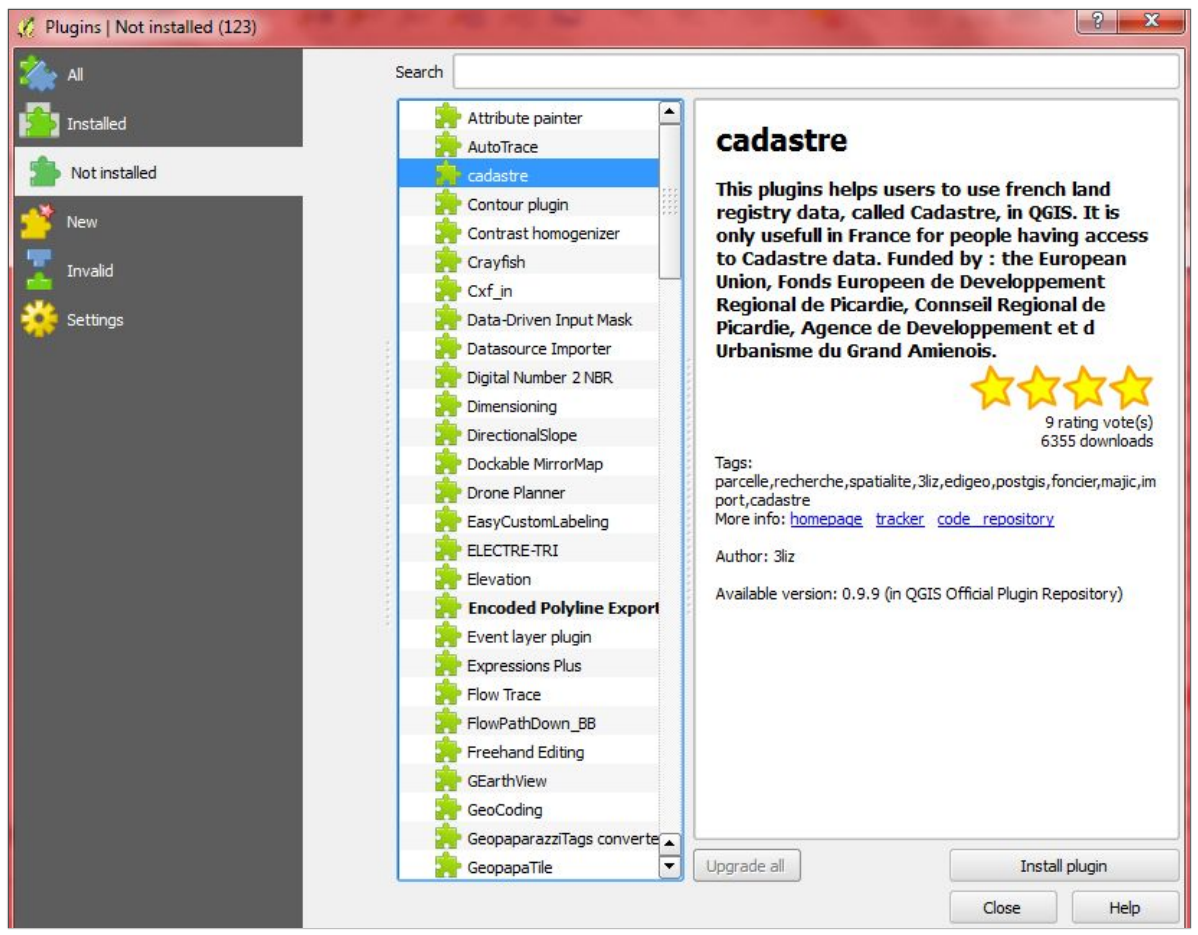




\section{MENAMPILKAN DATA SPASIAL}

1. Buka QGIS melalui start -> all programs -> QGIS Valmiera -> QGIS Desktop 2.2 .0 atau klik ikon QGIS di desktop

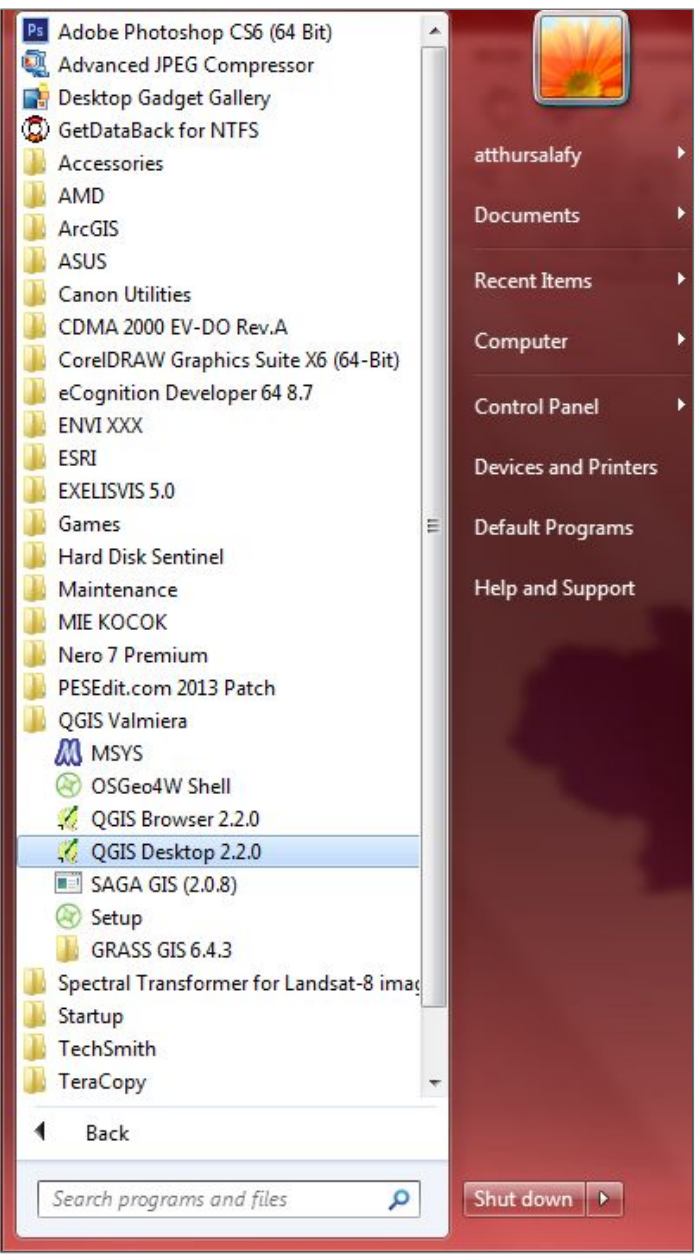

2. Klik menu layer -> add vector layer atau klik ikon add vector layer pada toolbar

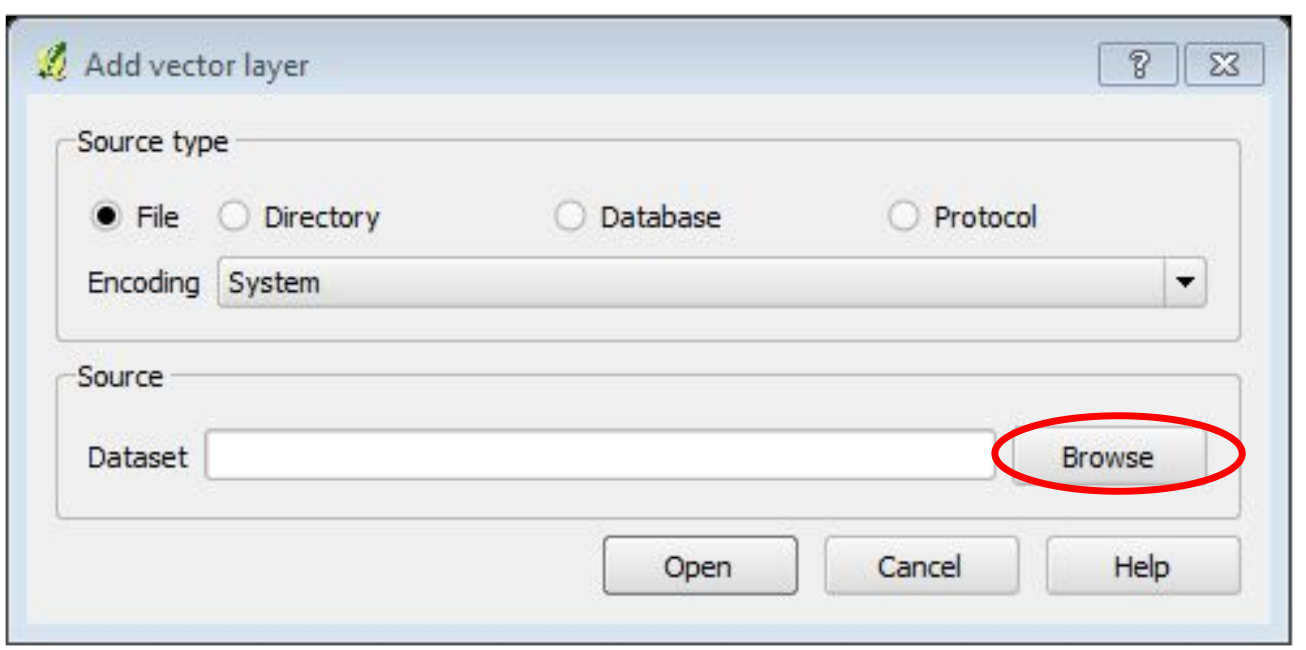


3. Klik Browse, lalu pilih file boalemo_kab-> open

4. Maka akan tersaji peta kab boalemo seperti pada gambar di bawah

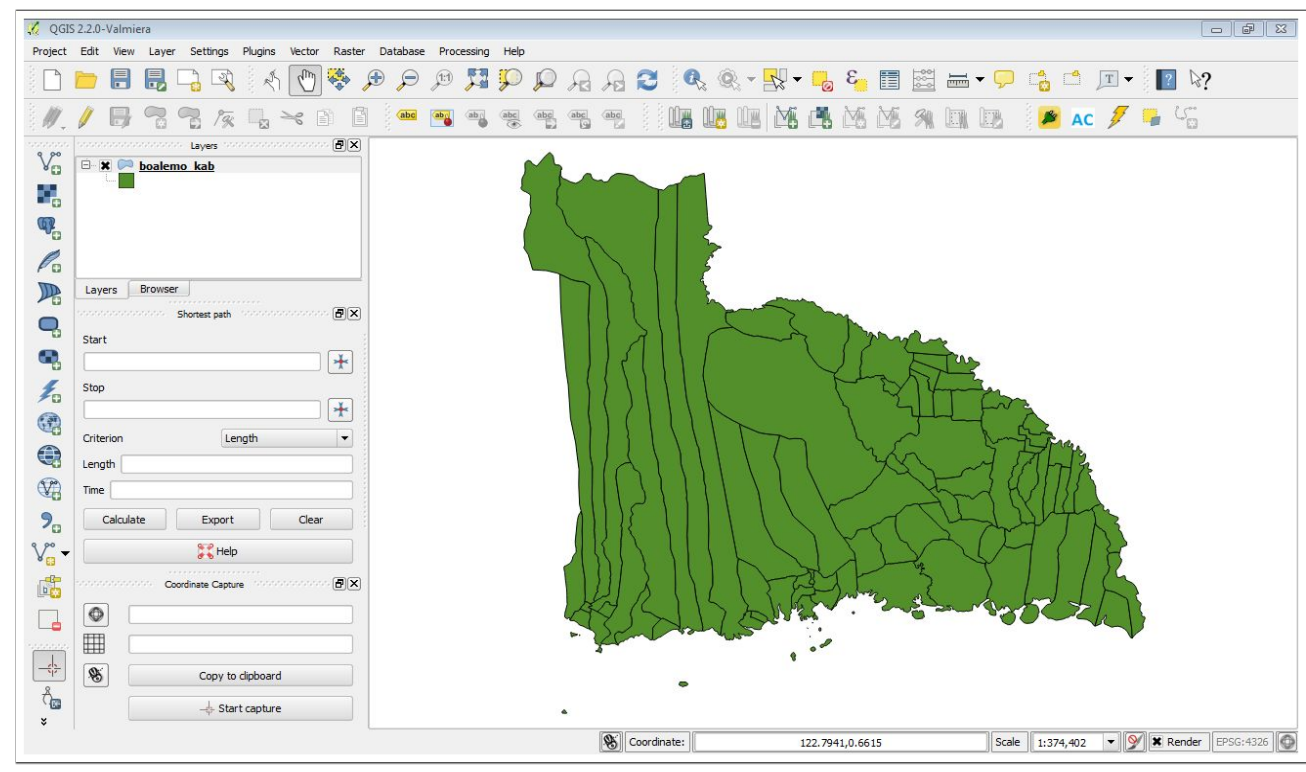

5. Untuk melihat tabel data boalemo_kab, klik kanan file-> open attribute table atau klik ikon open attribute table pada toolbar. Maka akan muncul attribut table boalemo_kab

\begin{tabular}{|c|c|c|c|c|c|c|c|c|c|c|}
\hline \multicolumn{8}{|c|}{1 Attribute table - boalemo_kab :: Features total: 84 , filtered: 84 , selected: 0} & \multirow[t]{2}{*}{$\square$} & 回 & \multirow{2}{*}{$\begin{array}{l}83 \\
?\end{array}$} \\
\hline ( & ]回 $[0$ & $\varepsilon$ 包电 & [8. & [용 & 同 & & & & & \\
\hline & PROVINSI & KECAMATAN & DESA & SUMBER & KODE 2010 & PROVNO & KABKOTNO & & \multicolumn{2}{|c|}{$\mathrm{KECN}-$} \\
\hline 0 & GORONTALO & PAGUYAMAN PA... & BUBAA & SP2010_BADAN ... & 7501052002 & 75 & 01 & & 052 & \\
\hline 1 & GORONTALO & PAGUYAMAN PA... & LITO & SP2010_BADAN ... & 7501052003 & 75 & 01 & & 052 & \\
\hline 2 & GORONTALO & PAGUYAMAN PA... & BUKIT KARYA & SP2010_BADAN ... & 7501052004 & 75 & 01 & \multicolumn{2}{|c|}{052} & \\
\hline 3 & GORONTALO & PAGUYAMAN PA... & APITALAWU & SP2010_BADAN ... & 7501052005 & 75 & 01 & & 052 & \\
\hline 4 & GORONTALO & PAGUYAMAN PA... & OLIBU & SP2010_BADAN ... & 7501052006 & 75 & 01 & & 052 & \\
\hline 5 & GORONTALO & PAGUYAMAN PA... & TOWAYU & SP2010_BADAN ... & 7501052007 & 75 & 01 & & 052 & \\
\hline 6 & GORONTALO & PAGUYAMAN PA... & BANGGA & SP2010_BADAN ... & 7501052008 & 75 & 01 & & 052 & \\
\hline 7 & GORONTALO & PAGUYAMAN PA... & LIMBATIHU & SP2010_BADAN ... & 7501052001 & 75 & 01 & & 052 & \\
\hline 8 & GORONTALO & WONOSARI & MEKAR JAYA & SP2010_BADAN ... & 7501051001 & 75 & 01 & & 051 & \\
\hline 9 & GORONTALO & WONOSARI & MAKMUR & SP2010_BADAN ... & 7501051004 & 75 & 01 & & 051 & \\
\hline 10 & GORONTALO & WONOSARI & JATI MULYA & SP2010_BADAN ... & 7501051007 & 75 & 01 & & 051 & \\
\hline 11 & GORONTALO & WONOSARI & TRI RUKUN & SP2010_BADAN ... & 7501051008 & 75 & 01 & & 051 & \\
\hline 12 & GORONTALO & WONOSARI & RAHARJA & SP2010_BADAN ... & 7501051009 & 75 & 01 & & 051 & \\
\hline 13 & GORONTALO & WONOSARI & TANJUNG HARAP... & SP2010_BADAN ... & 7501051013 & 75 & 01 & & 051 & \\
\hline 14 & GORONTALO & WONOSARI & DULOHUPO & SP2010_BADAN ... & 7501051014 & 75 & 01 & & 051 & \\
\hline 15 & GORONTALO & PAGUYAMAN & MOLOMBULAHE & SP2010_BADAN ... & 7501050005 & 75 & 01 & & 050 & $\Delta$ \\
\hline 16 & GORONTALO & PAGUYAMAN & WONGGAHU & SP2010_BADAN ... & 7501050006 & 75 & 01 & & 050 & 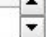 \\
\hline 1 & & & & & & & & & 11 & - \\
\hline & Show All Features. & & & & & & & & : & 闌 \\
\hline
\end{tabular}


6. Mengetahui informasi dari suatu wilayah, klik ikon identify features atau klik menu View -> indentify features. Lalu klik salah satu polygon

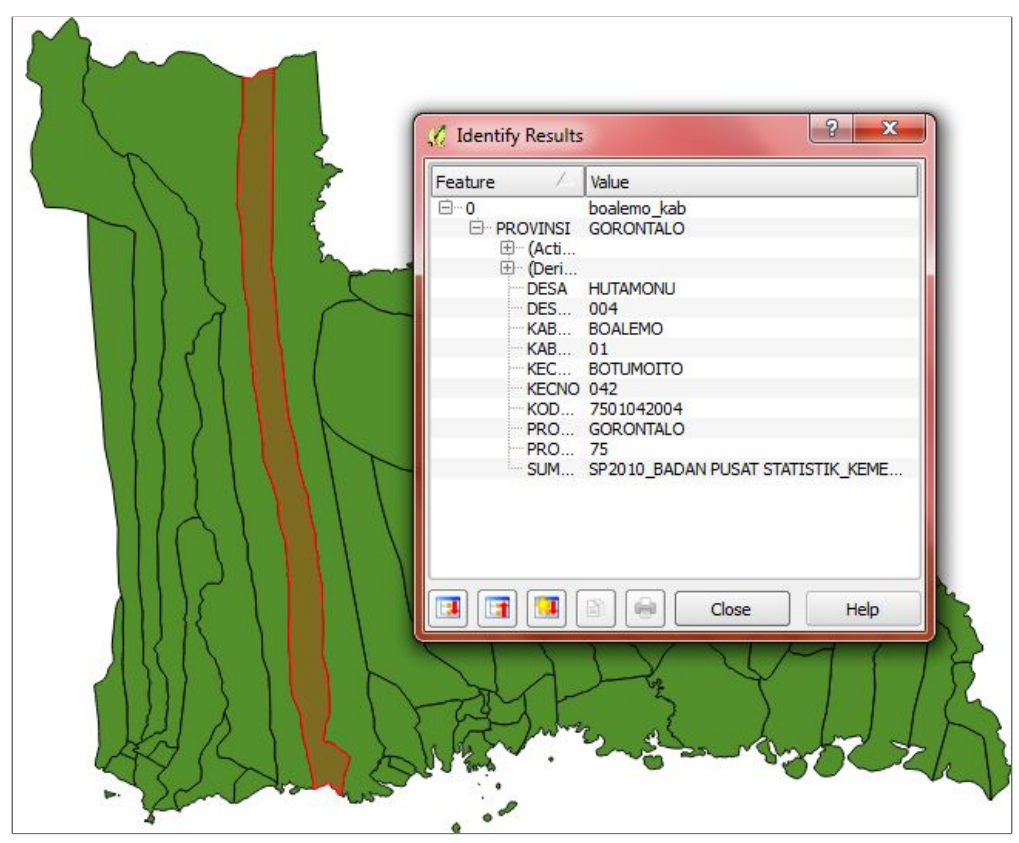

7. Perhatikan pula koordinat dan skala pada saat data spasial boalemo_kab tersaji

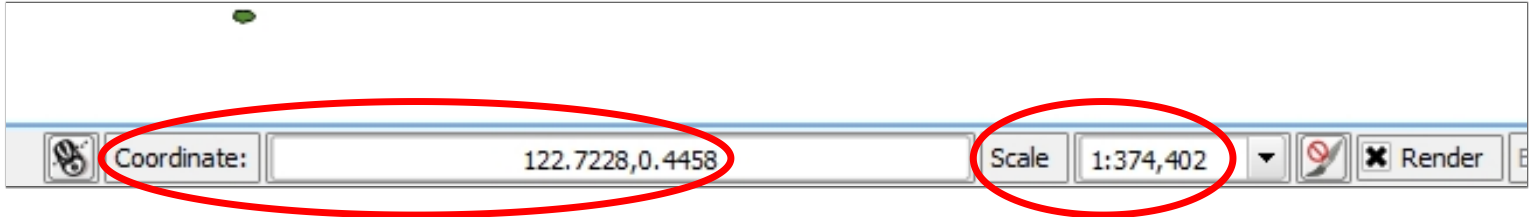

8. Sama seperti point ke2, klik add vector layer lalu tambahkan file kota.shp

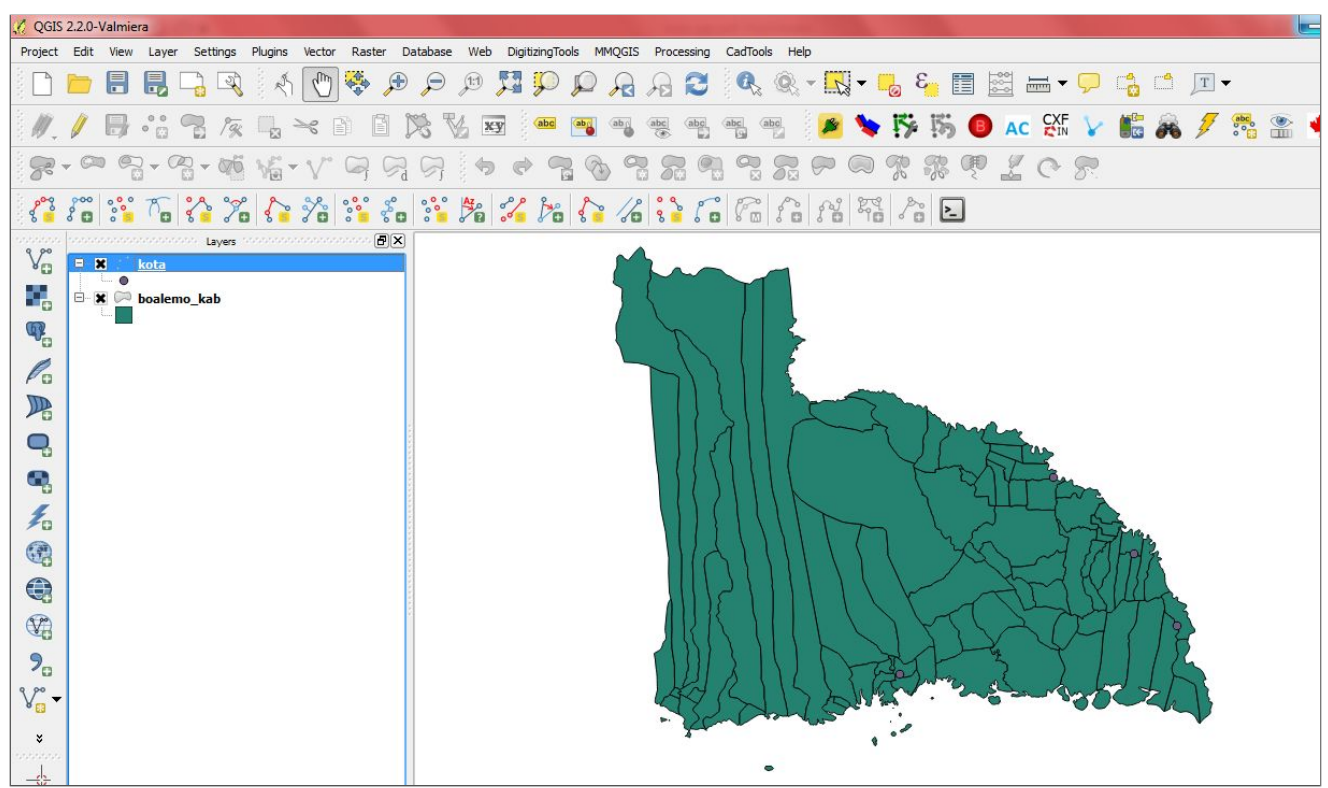


9. Untuk melihat tabel data kota, klik kanan file-> open attribute table atau klik ikon open attribute table pada tool bar. Maka akan muncul tabel attribut kota

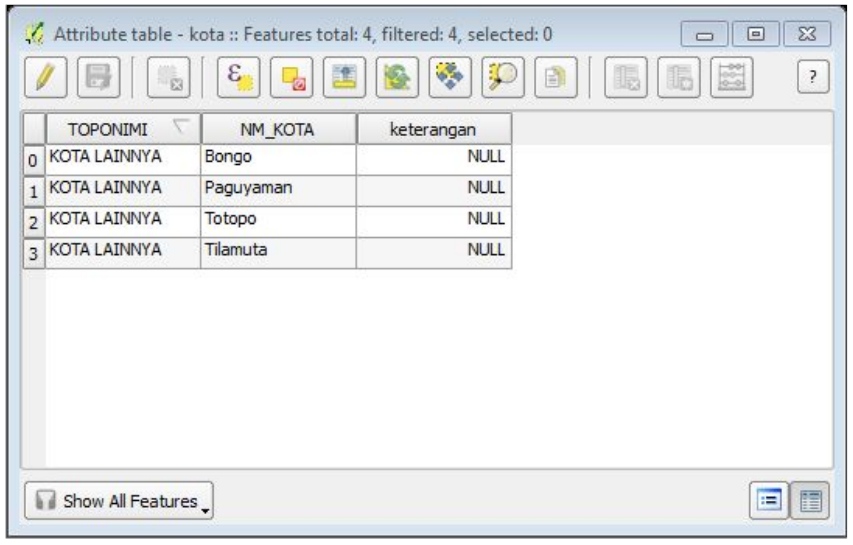

10. QGIS dapat pula menampilkan data raster, klik ikon add raster layer -> gorontalo_utm -> maka akan muncul jendela bahwa file raster belum tergeoreference -> klik ok
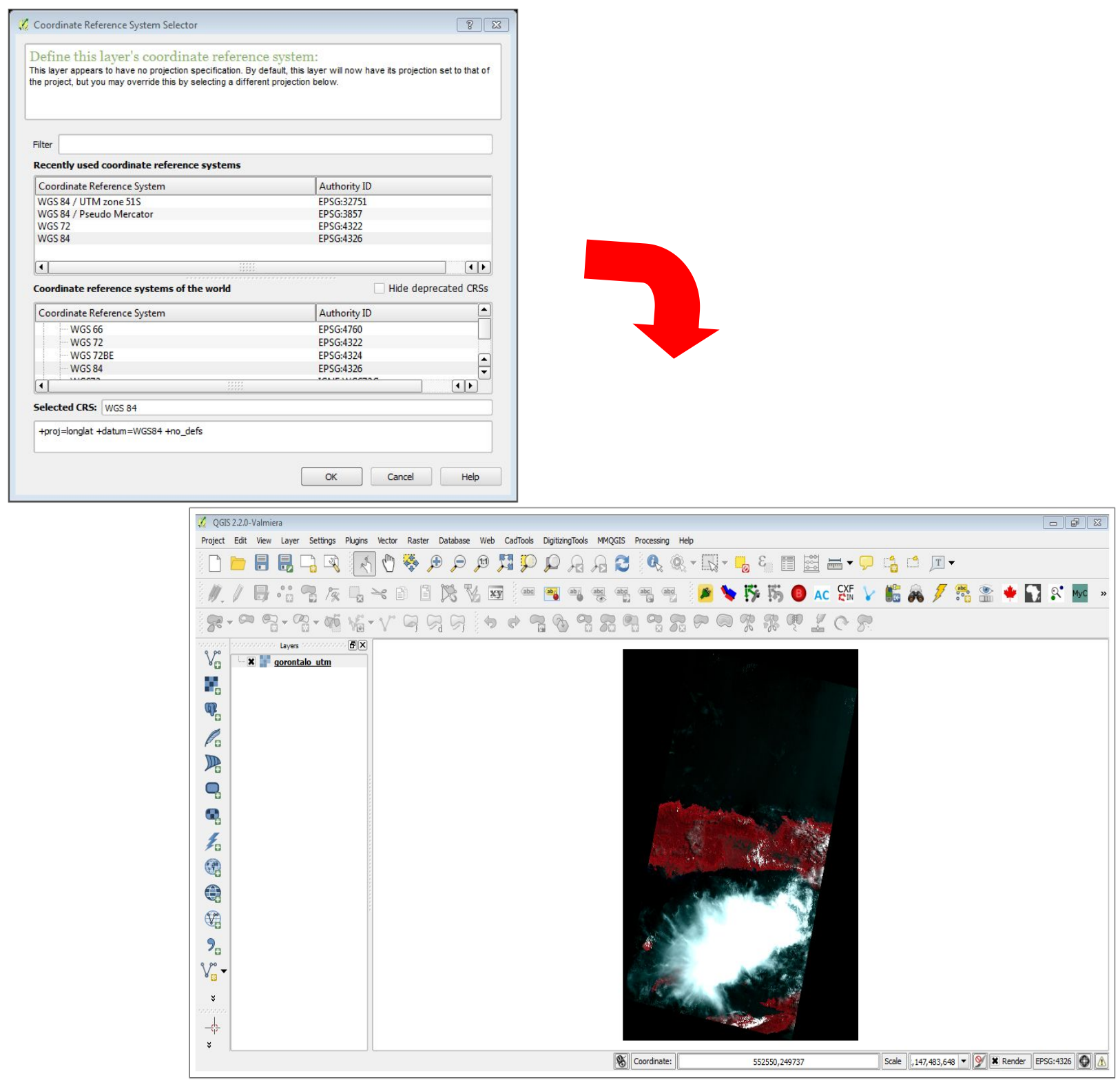


\section{Contoh soal latihan dan Tugas}

1. Buka data vector (point, line dan polygon) dan amati attribute tabelnya

2. Buka pula data raster dan amati informasi yang terkandung didalamnya 


\section{MENGELOLA LAYER}

\subsection{On/Off Layer}

Untuk dapat mematikan dan menyalakan layer dengan cara klik pada kotak di sebelah nama layer pada table of content (TOC)
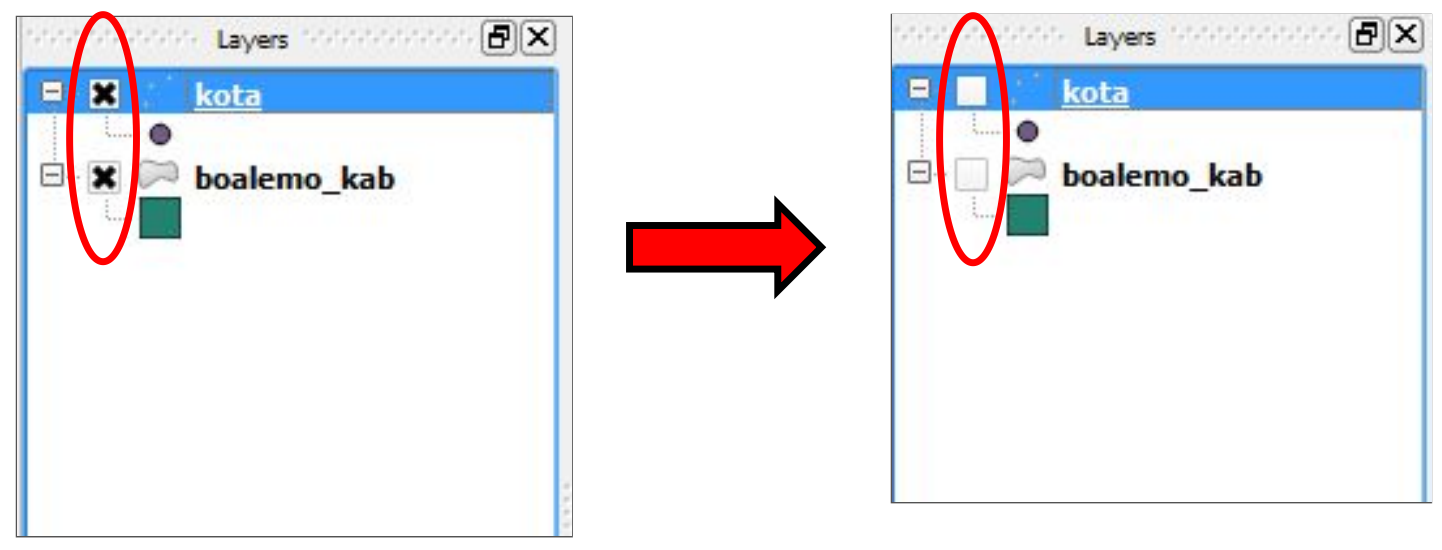

Berlatihlah untuk mematikan dan menyalakan layer, dan lihat hasilnya pada Data frame anda.

\subsection{Mengubah Susunan Layer}

Mengubah susunan layer digunakan untuk mengubah urutan layer. Susunan layer sangat berpengaruh pada penampakan di layer. Jika layer kota berada di bawah layer boalemo_kab, maka layer kota tidak tampak di data frame karena tertutup oleh boalemo_kab.

Cara mengubah susunan layer dilakukan dengan Drag-and-Drop layer yang bersangkutan :

$>$ Klik dan Tahan pada layer kota

$>$ Tarik (mouse masih ditahan) layer kota ke atas layer boalemo_kab

$>$ Lepaskan Mouse

\subsection{Mengubah Nama Layer}

Untuk mengubah nama layer dapat dilakukan dengan cara berikut:

> Klik kanan pada layer kota lalu Pilih properties

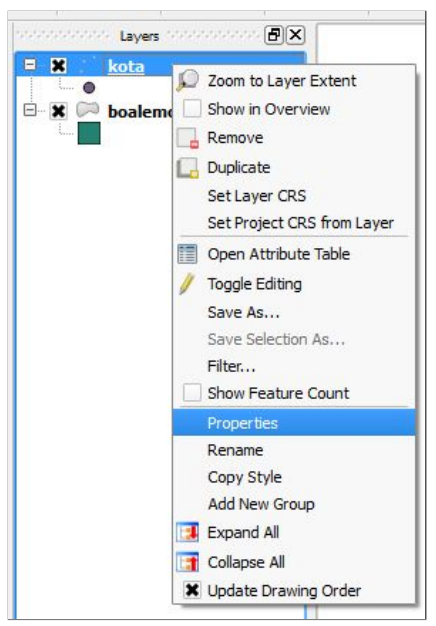


Pada jendela properties pilih tab General

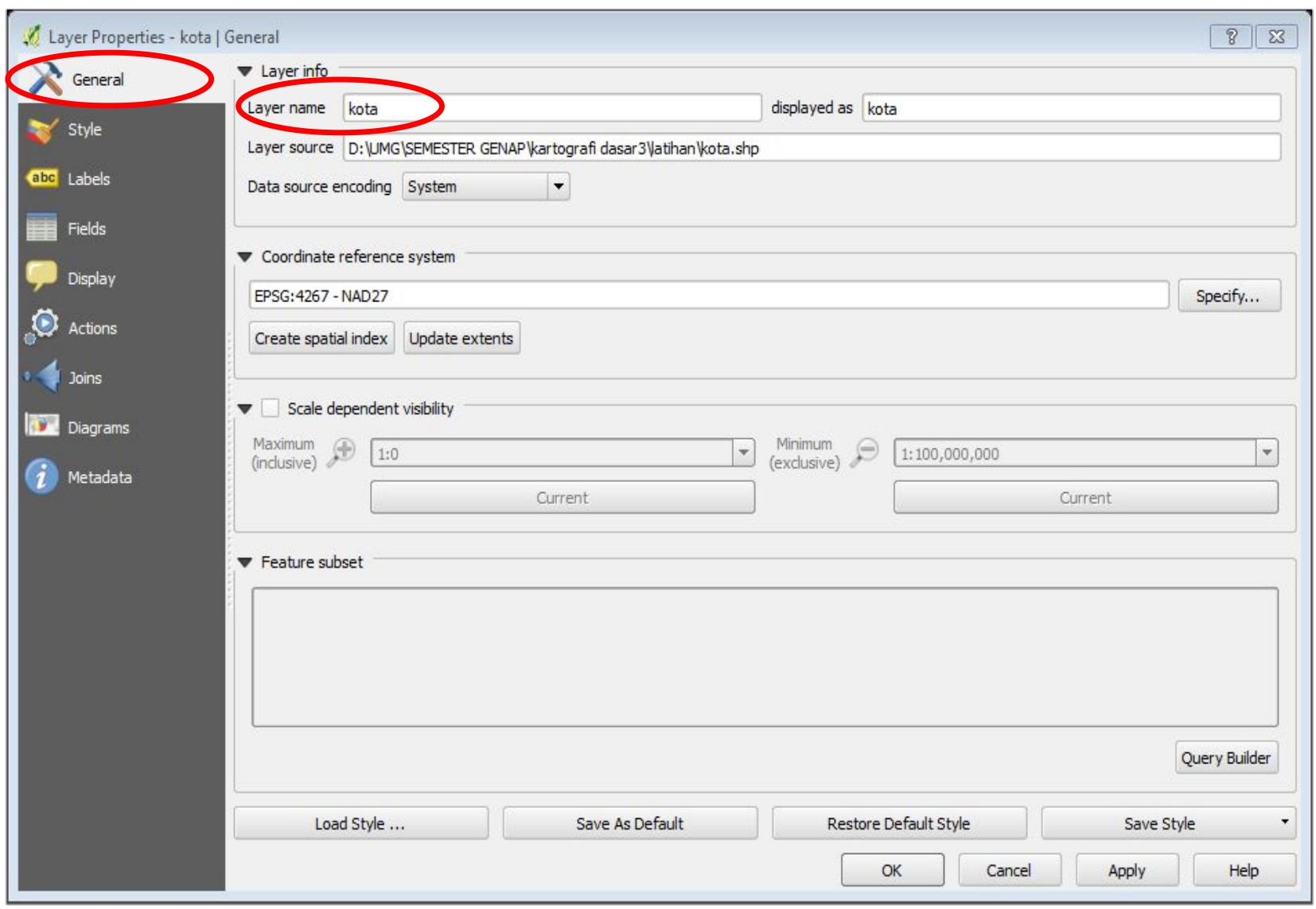

Anda dapat mengubah nama layer anda pada Display Name

$>$ Karena hanya link saja, pengubahan nama layer tidak berpengaruh pada file database anda.

\subsection{Memeriksa Fitur Data Vektor}

$>$ Bila ingin memeriksa informasi dari peta, klik polygon dengan menggunakan tool identify feature

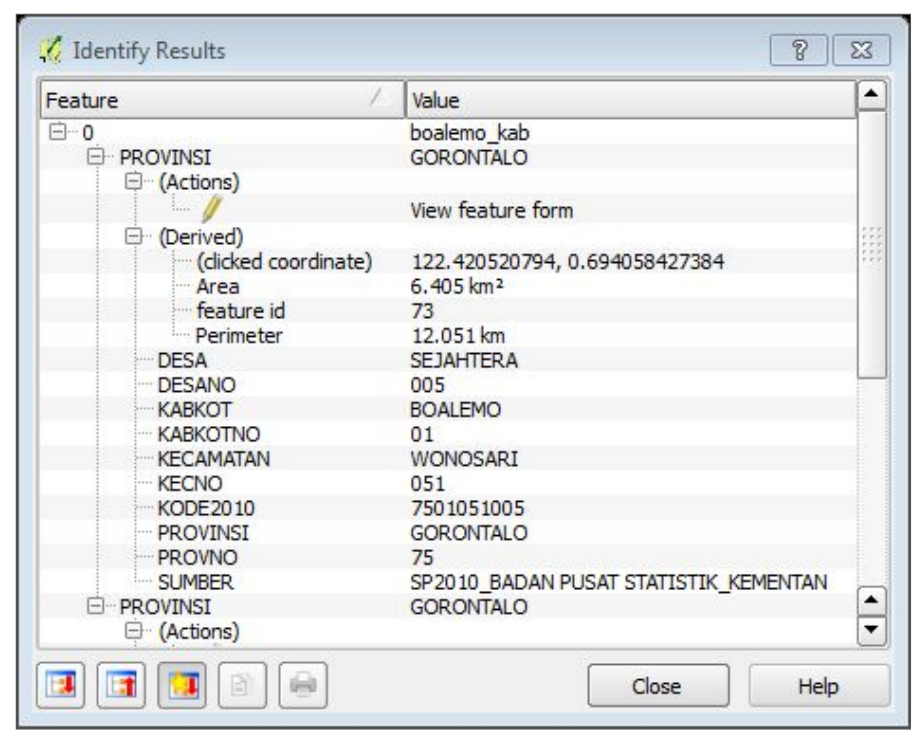




\subsection{Mengelola Tabel Atribut}

Pada panel layer di sebelah kiri QGIS, klik kanan pada layer boalemo_kab dan klik kanan Open attribute table

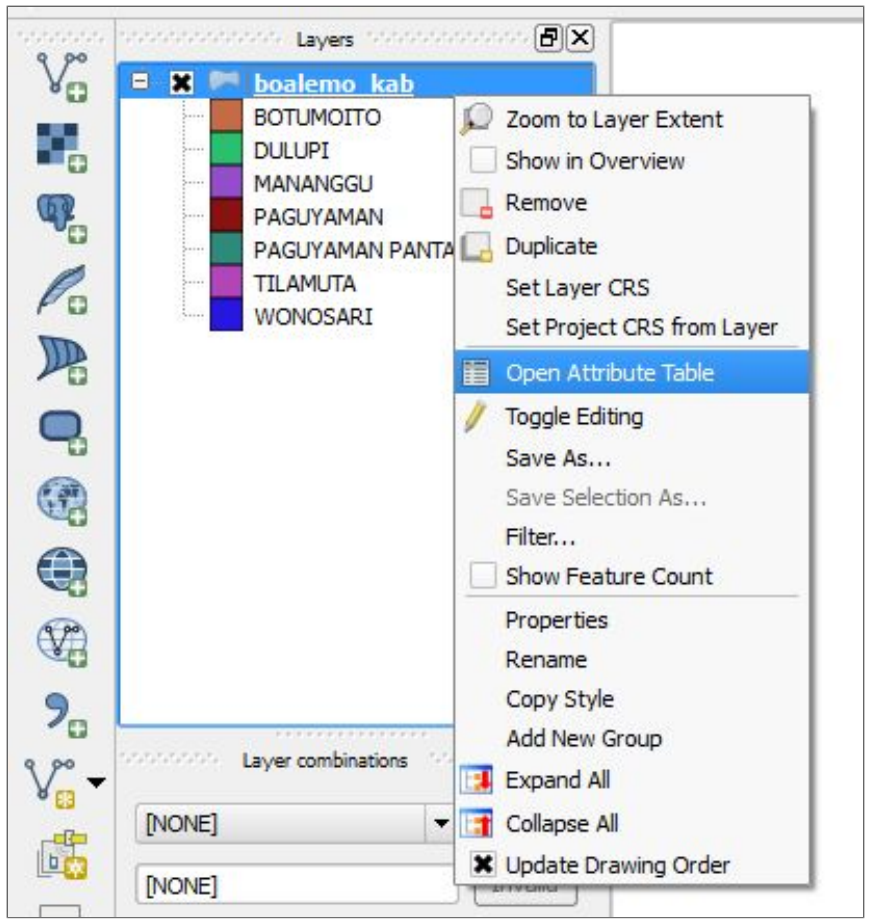

Maka akan muncul atribut tabel boalemo_kab

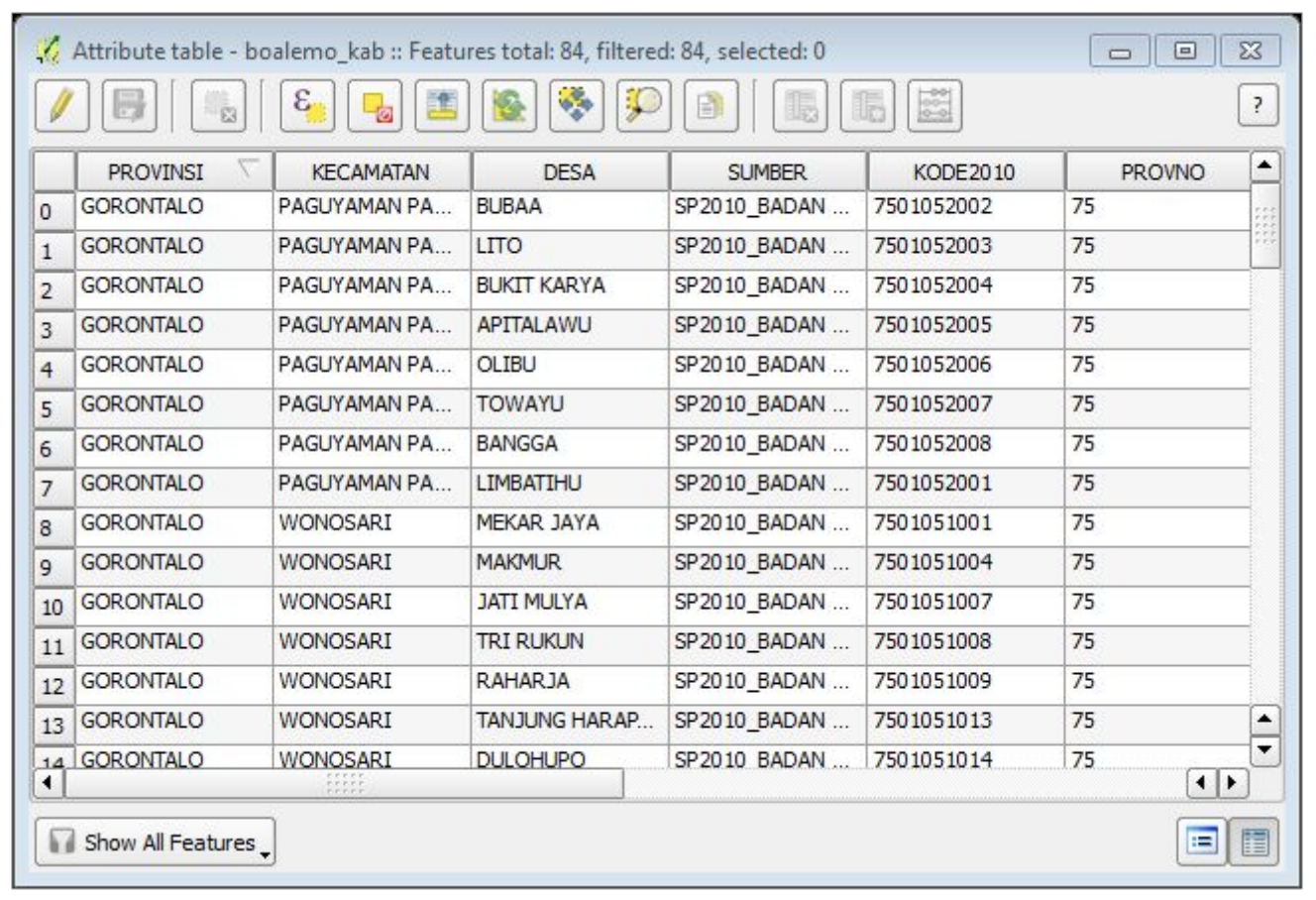




\subsection{Representasi Selected Feature}

Apabila anda klik di salah satu field, misalnya Desa Makmur kemudian klik ikon

pada tabel, lalu kembali ke peta anda, anda akan melihat lokasi dimana titik yang anda pilih tersebut direpresentasikan dalam peta

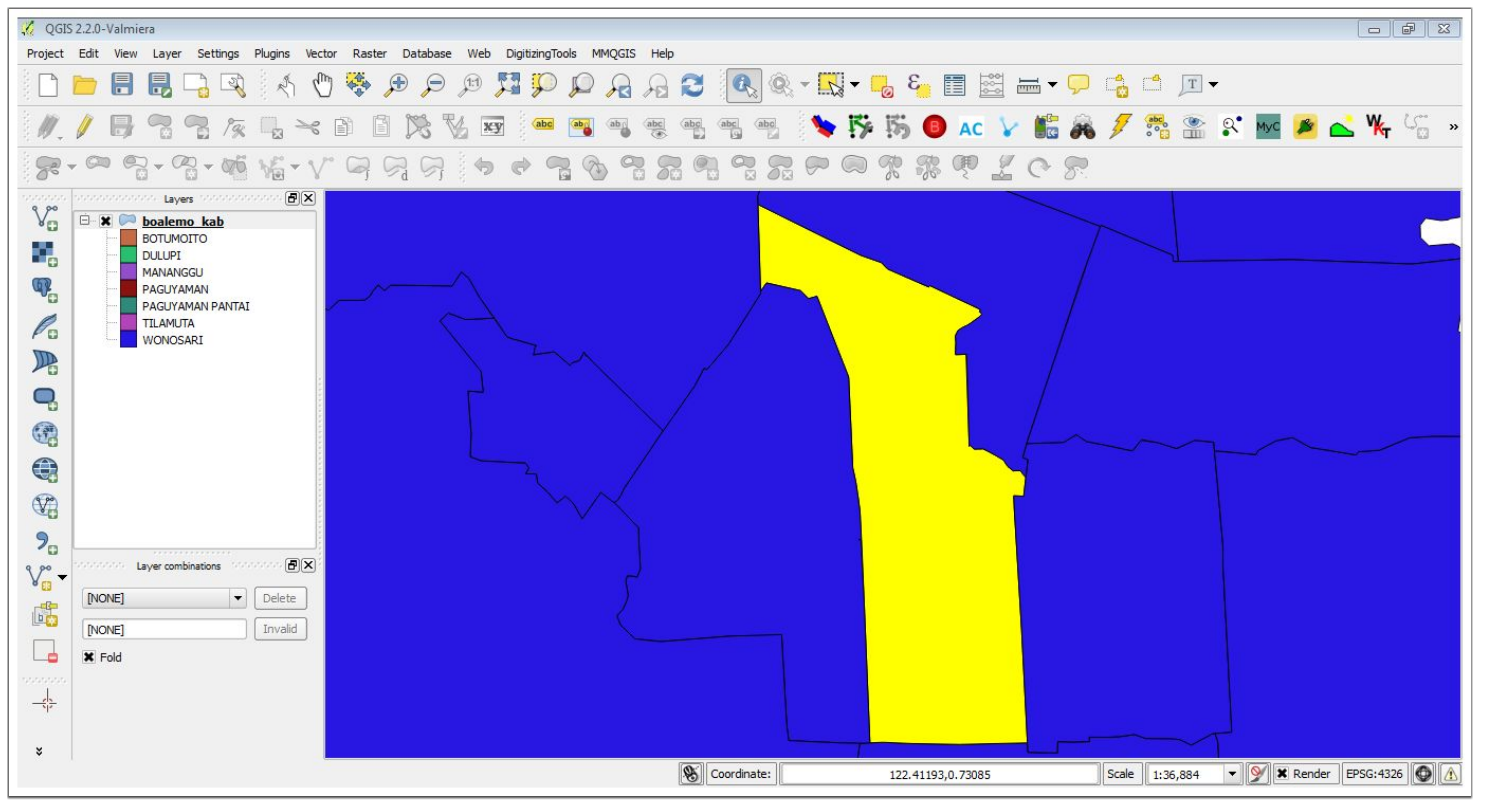

Hal ini juga berlaku sebaliknya, apabila anda menggunakan fungsi Select Single Feature pada peta, hasil seleksi juga terepresentasikan pada tabel atributnya.

\subsection{Mengatur Maptips}

Maptips juga dapat digunakan untuk melihat data atribut, untuk mengatur data yang ditampilkan oleh maptips dapat di atur dengan cara berikut :

$>$ Klik kanan pada layer > Properties

$>$ Kemudian pada jendela properties pilih tab Display

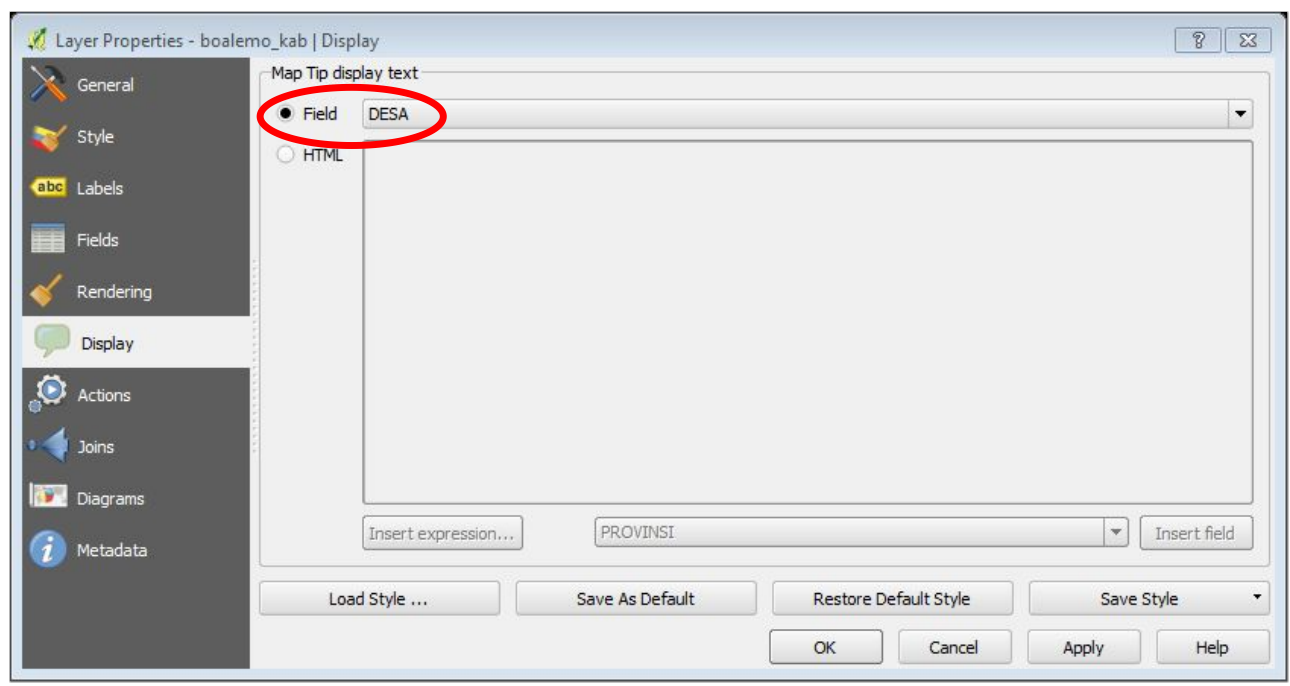


Pada tab Display pilih field yang ingin anda tampilkan pada Maptips anda, misalkan Desa

$>$ Klik OK

$>$ Klik ikon Maptips pada Toolbar

> Arahkan kursor ke Boalemo_kab maka anda akan mengetahui informasi nama desa

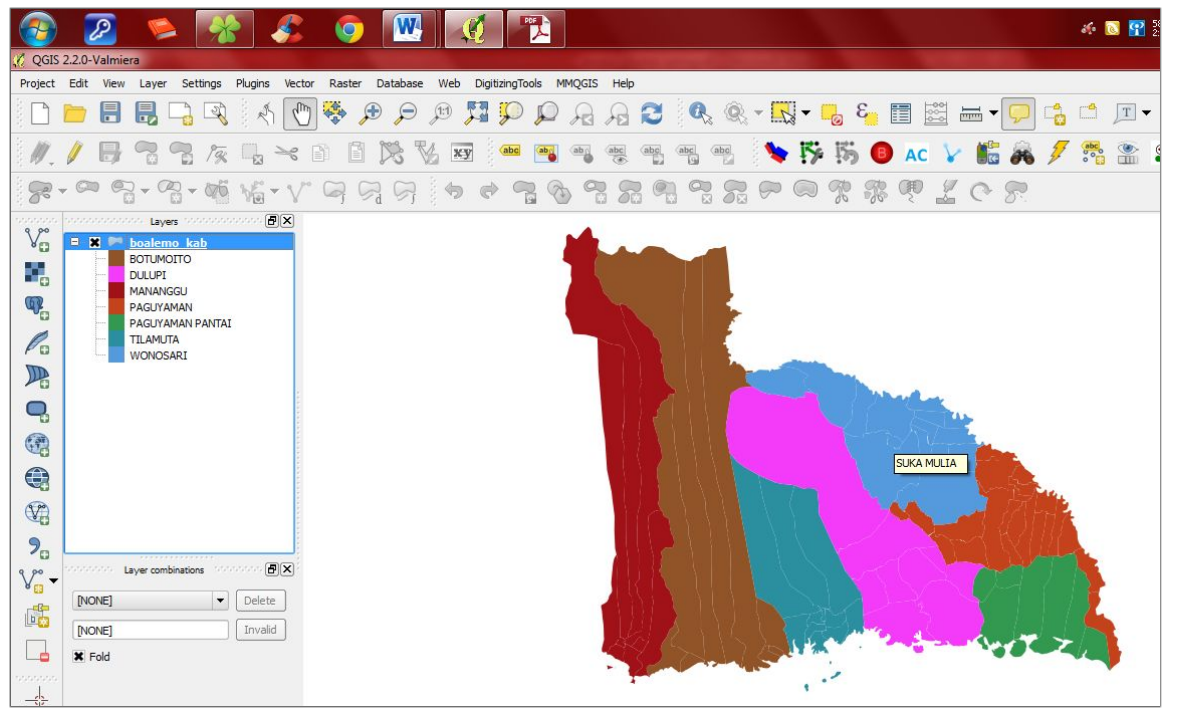

\subsection{Jarak Kumulatif}

Dapatkah kita menjawab pertanyaan "Berapa jarak Paguyaman ke Tilamuta??" Pertanyaan tersebut dapat dijawab dengan Measure Tools

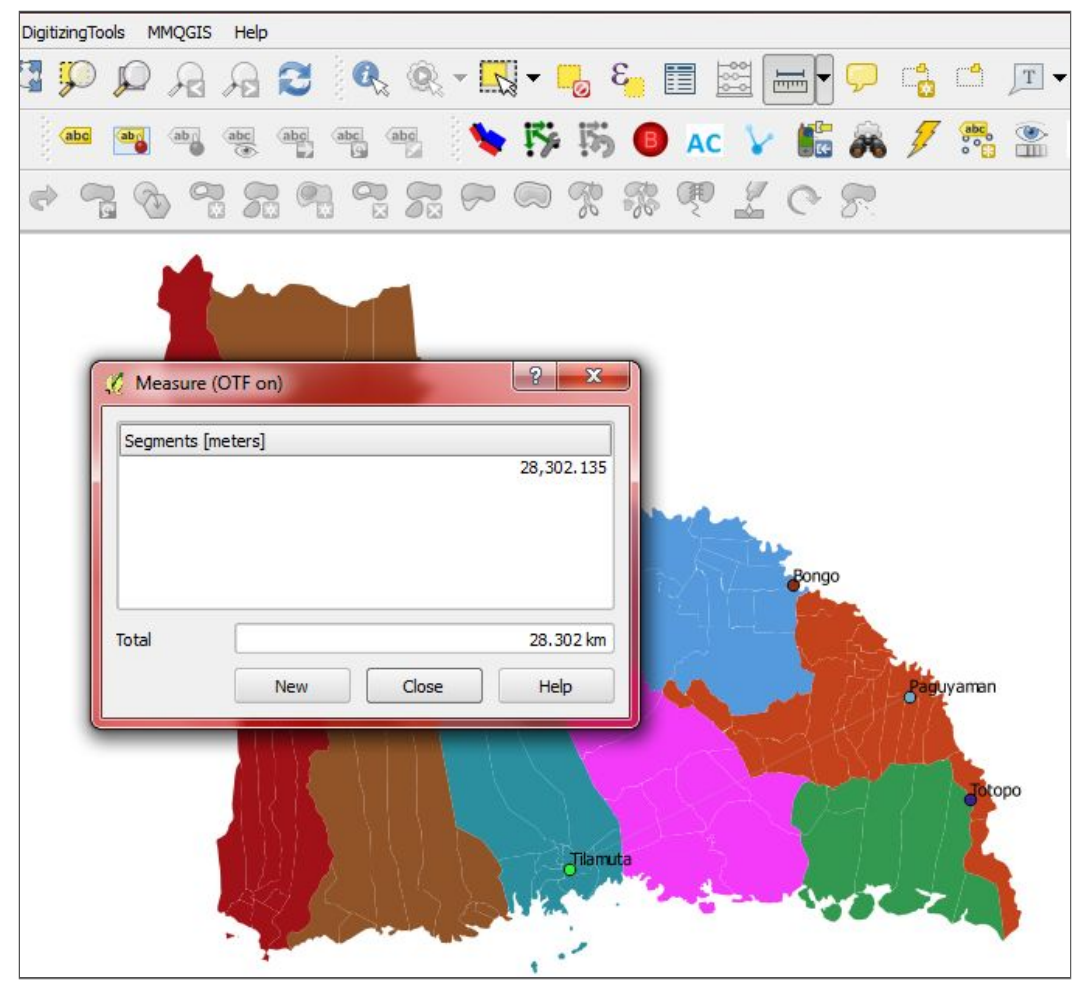




\subsection{Skala}

Skala adalah perbandingan antara jarak pada model (peta) dan jarak sebenarnya dilapangan. Mengatur skala adalah salah satu cara yang dapat digunakan mengatur zoom karena skala dapat berperan sebagai Zoom level. Skala pada peta tersebut ditampilkan pada Toolbar di bagian bawah jendela utama QGIS.

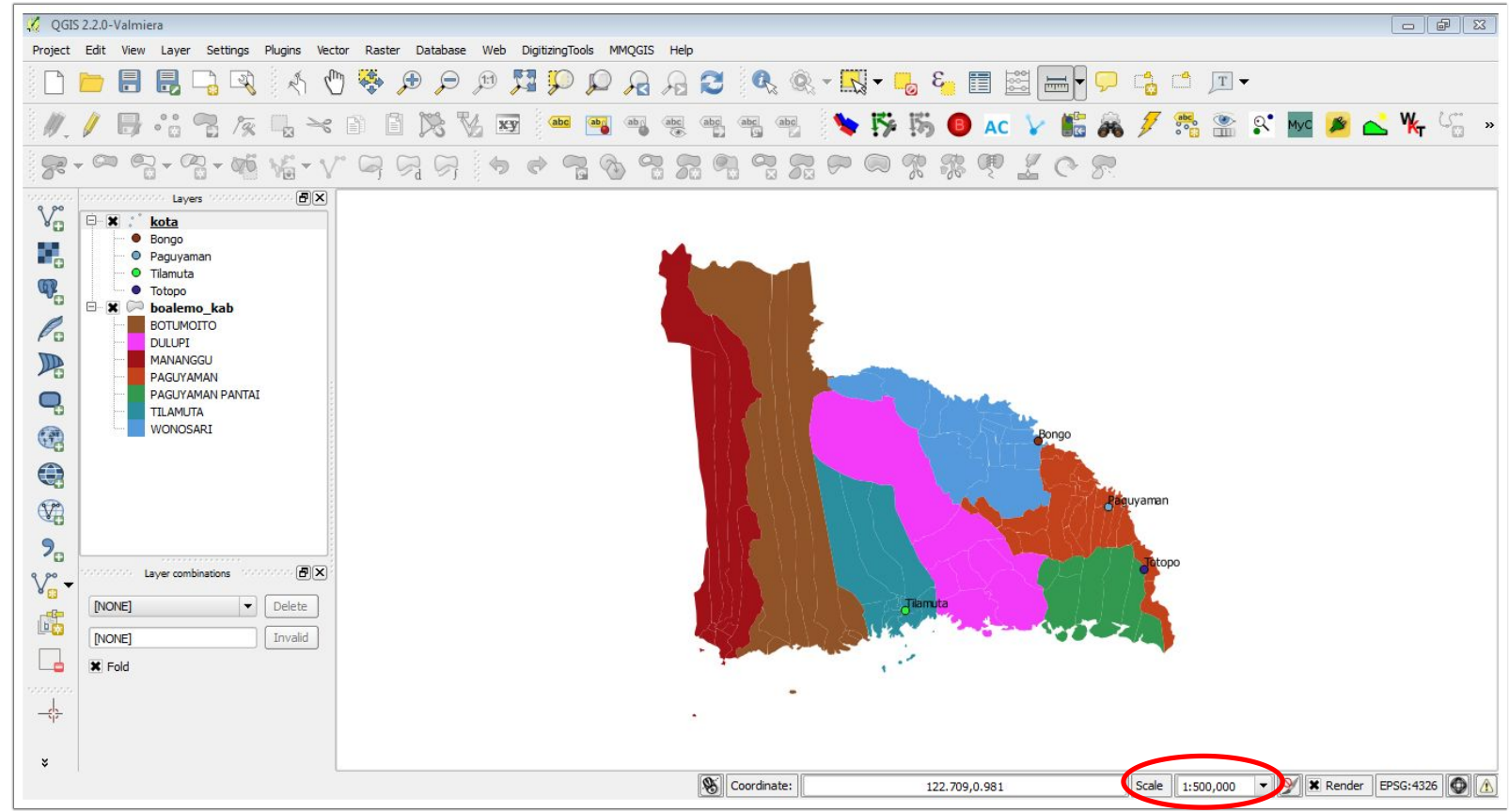

\subsection{Membuat Bookmarks}

Bookmark adalah salah satu alat navigasi yang praktis. Bookmark berfungsi untuk menyimpan informasi zoom dan pan pada suatu kondisi tertentu. Sehingga kita bisa dengan mudah menampilkan zoom dan pan itu kembali.

Contoh penggunaan Bookmarks adalah sebagai berikut:

$>$ Zoom in pada Kec. Wonosari

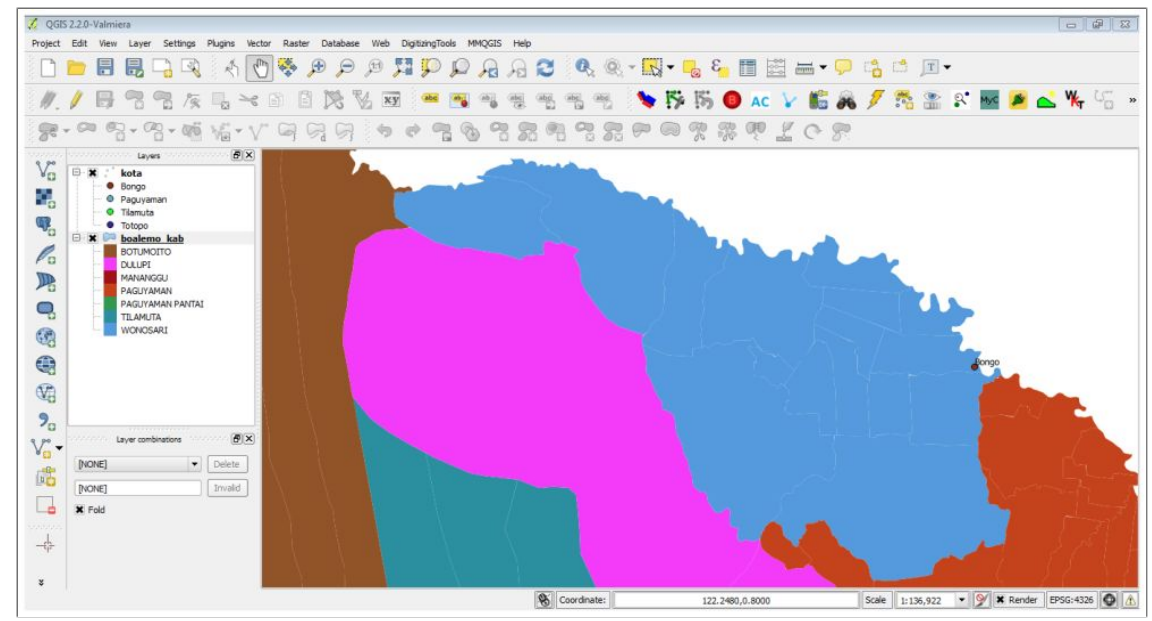


Klik NewBookmarks pada Toolbars

Pada kotak dialog Boorkmark, isi pada kolom Nama lalu tekan Enter, lalu close

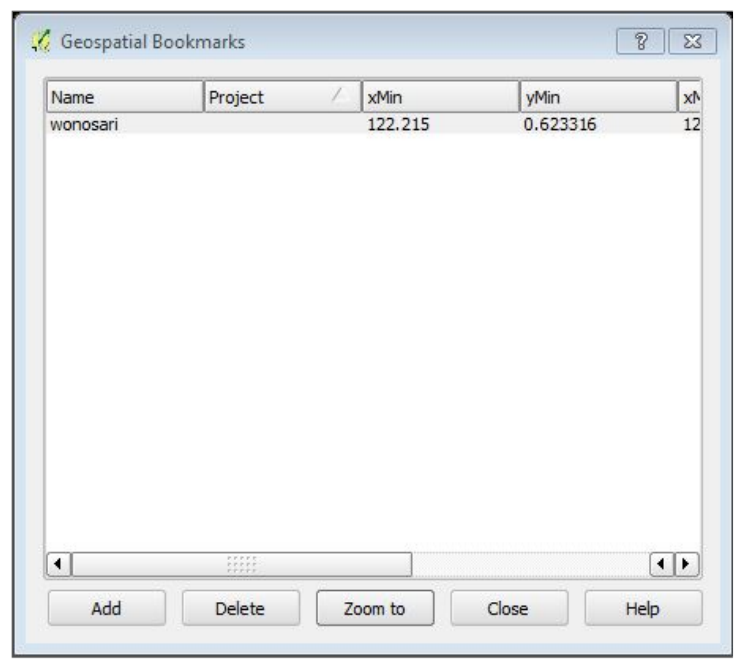

> Kembali ke Map Project anda, klik Zoom Full untuk melihat peta secara keseluruhan

$>$ Untuk melihat Bookmarks yang telah anda buat tadi, klik Show Bookmarks

$>$ Kemudian pilih Bookmarks dengan nama wonosari, lalu klik Zoom to

\section{Contoh soal latihan dan tugas}

1. Lakukan masing-masing point diatas $(4.1$ - 4.10) secara berurutan lalu simpan projecta anda ! 


\section{GEOREFERENSI}

Jika kita mempunyai sebuah data raster yang berasal dari hasil scanning peta, Foto udara, dan citra satelit yang belum berisi informasi yang menunjukkan referensi spasial. Kemudian kita ingin melakukan digitasi berdasarkan data raster tersebut. Maka yang diperlukan adalah membuat peta hasil scan tersebut mempunyai koordinat dengan melakukan koreksi geometrik yaitu proses georefence data raster ke dalam sistem koordinat.

Georeference dapat diartikan sebagai pemberian titik ikat, atau memasukkan koordinat pada gambar peta. Proses georeference dalam QGIS dapat dilakukan dengan beberapa langkah yang diuraikan berikut :

$>$ Siapkan file raster yang akan diberi titik ikat

File raster yang bisa anda gunakan sebagai acuan dalam memberi titik ikat antara lain : Peta RBI (Rupa Bumi Indonesia), Citra Quickbird, IKONOS, GeoEye, Google Earth, Worldview. Data peta/citra yang digunakan sebagai acuan dalam memberikan titik ikat sangat tergantung pada kebutuhan pemetaan. Sebagai contoh anda dapat menggunakan peta dengan skala detail $(1: 10.000,1: 5000)$, atau citra satelit dengan resolusi spasial tinggi (40 $\mathrm{cm}, 60 \mathrm{~cm}$ ) untuk pemetaan kawasan perkotaan

$>$ Lakukan Penyiaman (scanning) pada file raster yang telah disiapkan

Apabila file raster yang anda miliki berupa hardcopy maka harus anda "digitalkan" terlebih dahulu. Untuk melakukan langkah ini anda membutuhkan scanner. Scan peta/citra tersebut dan simpan dalam format JPG, atau TIFF. Apabila file raster yang anda miliki sudah dalam format digital anda dapat melihat format-format file raster yang dapat didukung oleh QGIS. Format-format yang dapat didukung antara lain;

- Arc/Info Binary Grid

- Spatial Data Transfer Standard Grids

- Erdas Imagine

- GRASS Raster
- JPEG

- USGS ASCII DEM

- Arc/Info ASCII Grid

- GeoTIFF

$>$ Berikan titik ikat pada file raster yang telah disiapkan

$>$ Anda dapat juga memberikan titik ikat pada data raster/vektor yang anda miliki dengan mengacu pada data raster/vektor lain yang sudah bergeoreference

Untuk memberikan titik ikat dari file raster pada QGIS dapat dilakukan dengan menggunakan georeferencer, yang prosesnya dijelaskan dalam beberapa langkah berikut : 
1. Klik Plugins > Georeferencer > Georeferencer untuk memunculkan jendela "Georeferencer"

2. Kemudian klik icon "Open Raster" dan pilih lokasi dimana anda menyimpan file raster

3. Maka akan muncul kotak dialog pengaturan sistem koordinat data raster yang di pilih seperti berikut :

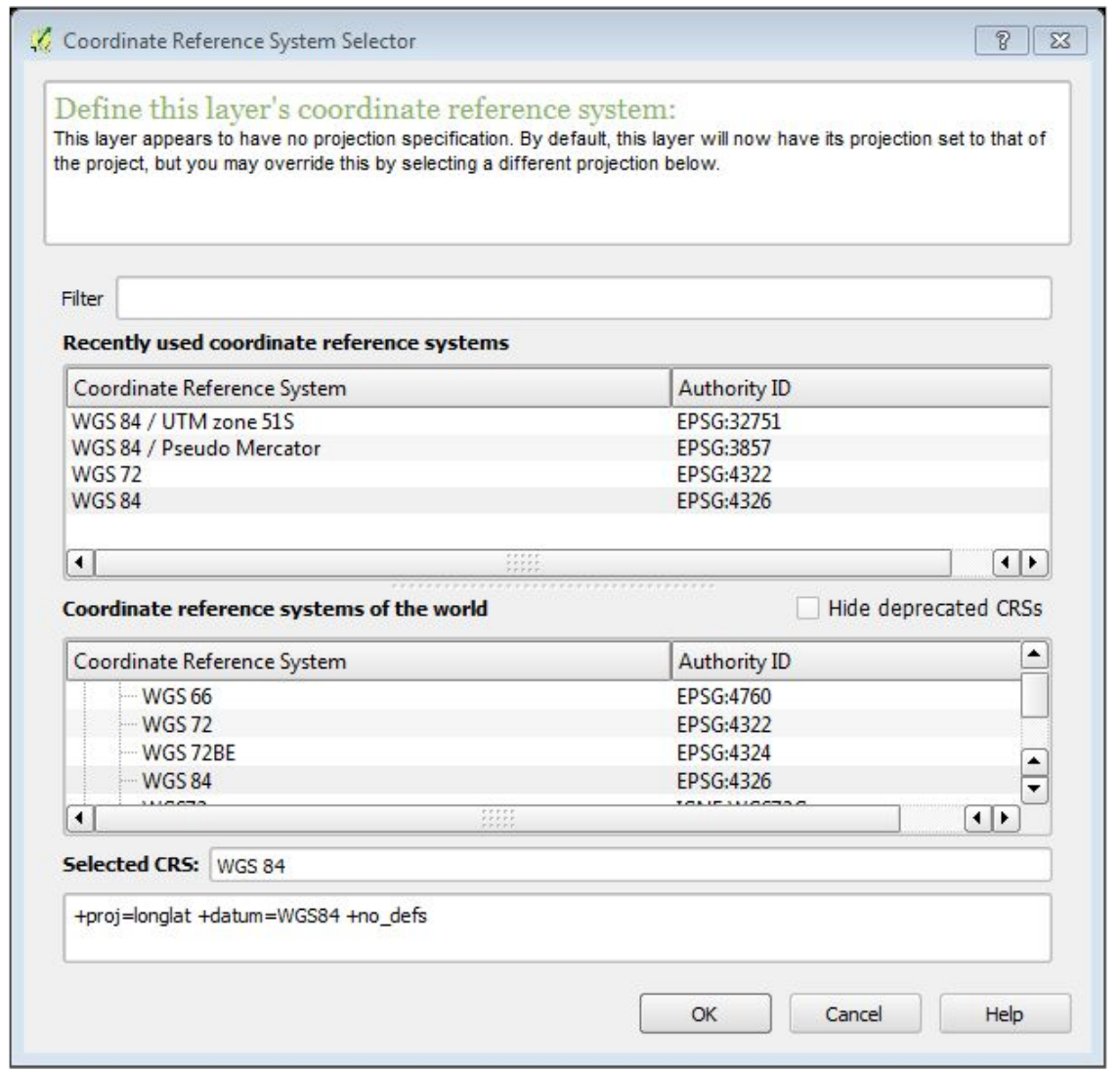

4. Klik cancel, lalu file raster anda akan terbuka

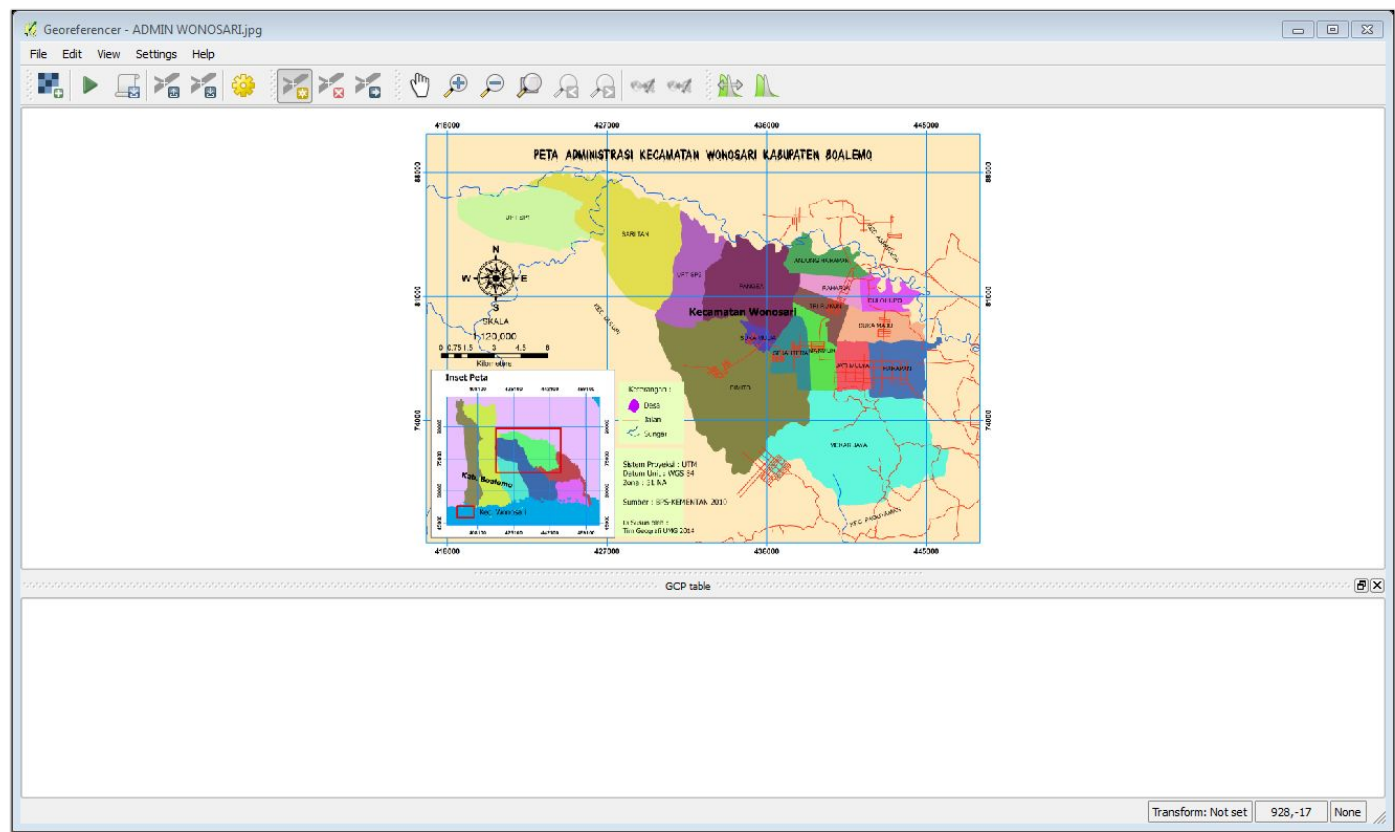


5. Setelah terbuka file raster anda, zoom sampai pada kenampakan dimana titik koordinat dapat terbaca, kecepatan dalam membuka file raster saat di zoom tergantung pada spesifikasi komputer yang anda gunakan

6. Mulai berikan titik ikat dengan "add point" icon pada beberapa lokasi yang tersebar merata pada file raster anda

7. Apabila ingin menghapus titik ikat yang anda telah buat dapat menggunakan Delete Point

8. Sedangkan bila ingin menggeser lokasi titik ikat menggunakan Move GCP Point dan arahkan pada titik ikat tersebut

9. Untuk memulai membuat titik ikat, pertama-tama Zoom pada keempat pojok/ sudut Peta untuk terlebih dahulu mengetahui lokasi dan nilai koordinat dari titik ikat yang akan digunakan

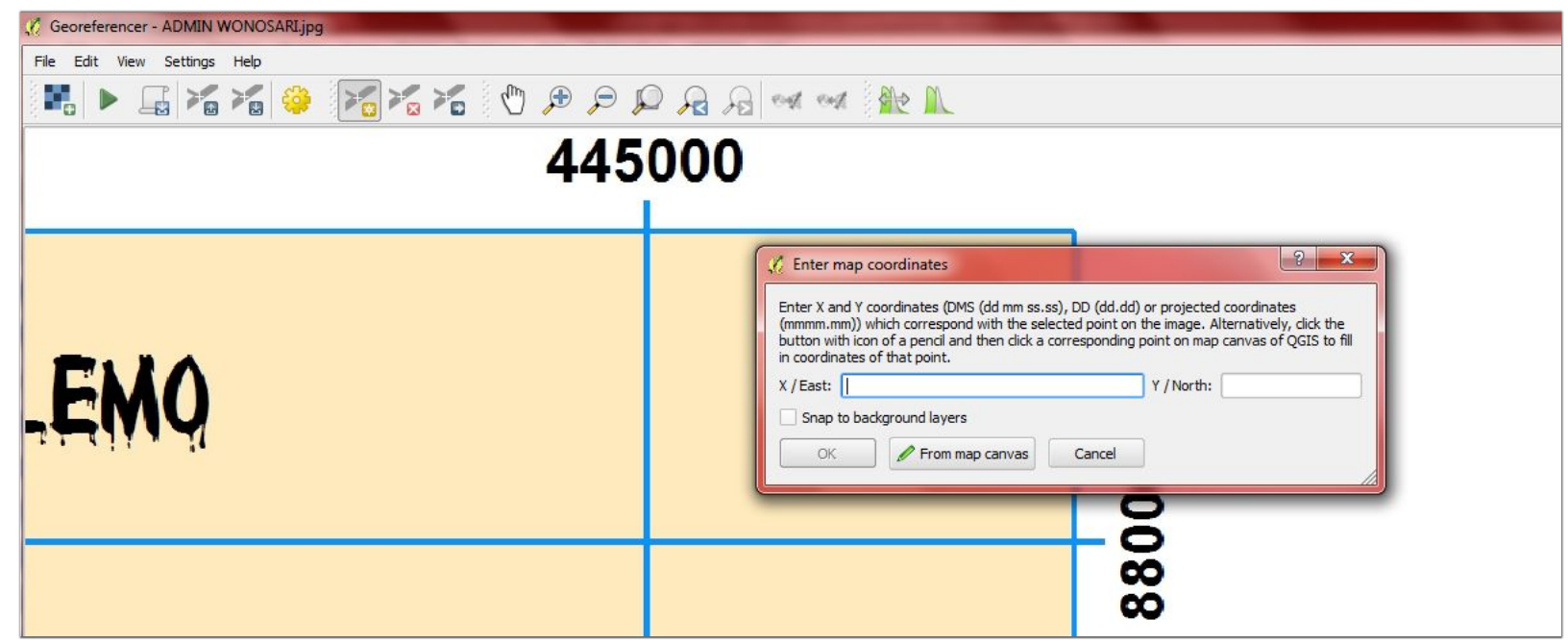

10. Lakukan langkah 9 untuk titik ikat yang berikutnya. Titik ikat disarankan minimal 4 buah

11. Kemudian untuk melanjutkan proses georeference, klik icon "Start georeferencing" dan tunggu prosesnya sampai selesai

\section{Contoh soal latihan dan tugas}

1. Lakukan georeferencing untuk data vector/data raster kemudian simpan hasilnya 


\section{PEMBUATAN LAYER}

Setelah anda memiliki data raster yang memiliki georeference, anda dapat memulai untuk membuat layer-layer baru diatasnya. Anda dapat memulai membuat data vektor baru berupa titik, garis atau poligon berdasarkan data raster yang telah memiliki georeference. Pada bab ini dibahas mengenai pembuatan data vektor baru berupa Point (titik), Line (garis) dan Polygon (Area).

\section{Pembuatan Layer Point (Titik)}

1) Untuk memulai membuat layer baru klik Layer > New > New Shapefile Layer

2) Setelah muncul jendela "New Vector Layer", Pilih "Point" pada pilihan dari type layer yang akan anda buat

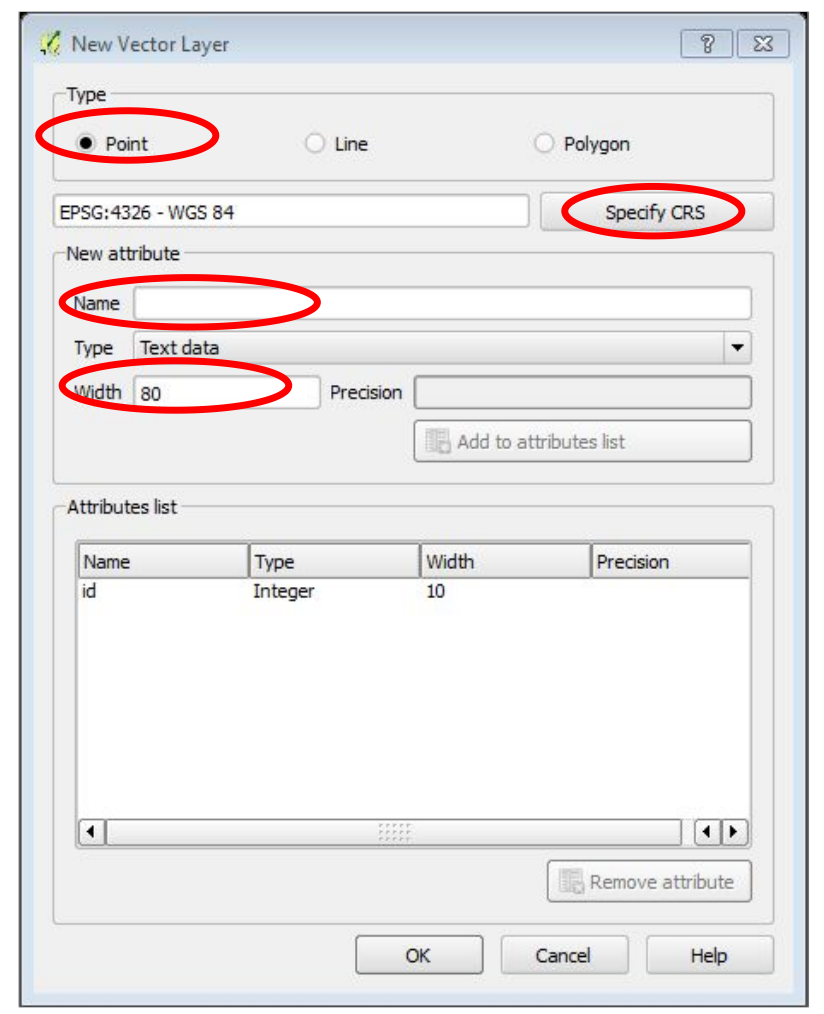

3) Beri nama kolom pada data atribut yang menyertai layer baru tersebut, tentukan type datanya serta atur lebar kolom yang akan disertakan ke dalam data atribut layer tersebut Keterangan :

- Tipe Point adalah jenis layer berupa titik digunakan untuk membuat Point of Interest

- Tipe Line adalah jenis layer berupa garis digunakan untuk membuat Jalan, garis kontur, Sungai....

- Tipe Polygon adalah jenis layer berupa area/ luasan digunakan untuk membuat Batas Administrasi, Landcover, Bangunan...... 
- Tentukan sistem koordinatnya, di Indonesia sistem koordinat yang dipakai WGS 1984. Apabila ingin menggunakan sistem koordinat UTM dengan zona UTM misalnya untuk wilayah Gorontalo paling cocok WGS1984 UTM $51 \mathrm{U}$

- Membuat Kolom pada data Atribut pada Groupbox New Attribute

- Buat nama kolom pada Name

- Tentukan tipe data yang ingin digunakan pada Type Tipe Data pada Atribut:

Text Data/ String : : Merupakan jenis data berupa teks

Whole number/Integer : Merupakan jenis data untuk bilangan bulat.

Decimal number/real : Merupakan jenis data untuk bilangan pecahan yang bisa dituliskan dalam bentuk decimal

- Atur panjangnya karakter yang dapat disimpan pada kolom, pada Width

- Khusus untuk tipe data Decimal Number anda bisa atur panjangnya karakter sesudah koma yang dapat disimpan pada kolom, pada Precision

- Sebagai catatan saja bahwa nama field terbatas hanya 10 karakter saja dan hanya bisa menggunakan huruf, angka, hypens dan underscores. Sepasang karakter dibolehkan tetapi tidak disarankan. Tidak bisa memberi nama field menggunakan spasi atau spesial karakter lainnya misalnya tanda tanya ( ? )

- Nama shapefile boleh max. 10 charakters (huruf, angka, underscore "_")

- Datatype adalah untuk mengatur apa yang diperbolehkan dimasuk di attribut field tersebut

a. Text Data/String adalah seluruh karakter termasuk alphanumeric. Maximum 255 karakter.

b. Whole Number/Integer adalah seluruh angka termasuk positif dan negatif yang biasanya digunakan untuk menunjukkan nilai banyak (kuantitas) dari suatu tema, misalnya populasi penduduk

\section{Pembuatan Layer Line (garis)}

1) Untuk memulai membuat layer baru klik Layer > New > New Shapefile Layer

2) Setelah muncul jendela "New Vector Layer", Pilih "Line" pada pilihan dari type layer yang akan anda buat

3) Beri nama kolom pada data atribut yang menyertai layer baru tersebut, tentukan type datanya serta atur lebar kolom yang akan disertakan ke dalam data atribut layer tersebut 


\section{Pembuatan Layer Polygon}

1) Untuk memulai membuat layer baru klik Layer $>$ New $>$ New Shapefile Layer

2) Setelah muncul jendela "New Vector Layer", Pilih "Polygon" pada pilihan dari type layer yang akan anda buat

3) Beri nama kolom pada data atribut yang menyertai layer baru tersebut, tentukan type datanya serta atur lebar kolom yang akan disertakan ke dalam data atribut layer tersebut

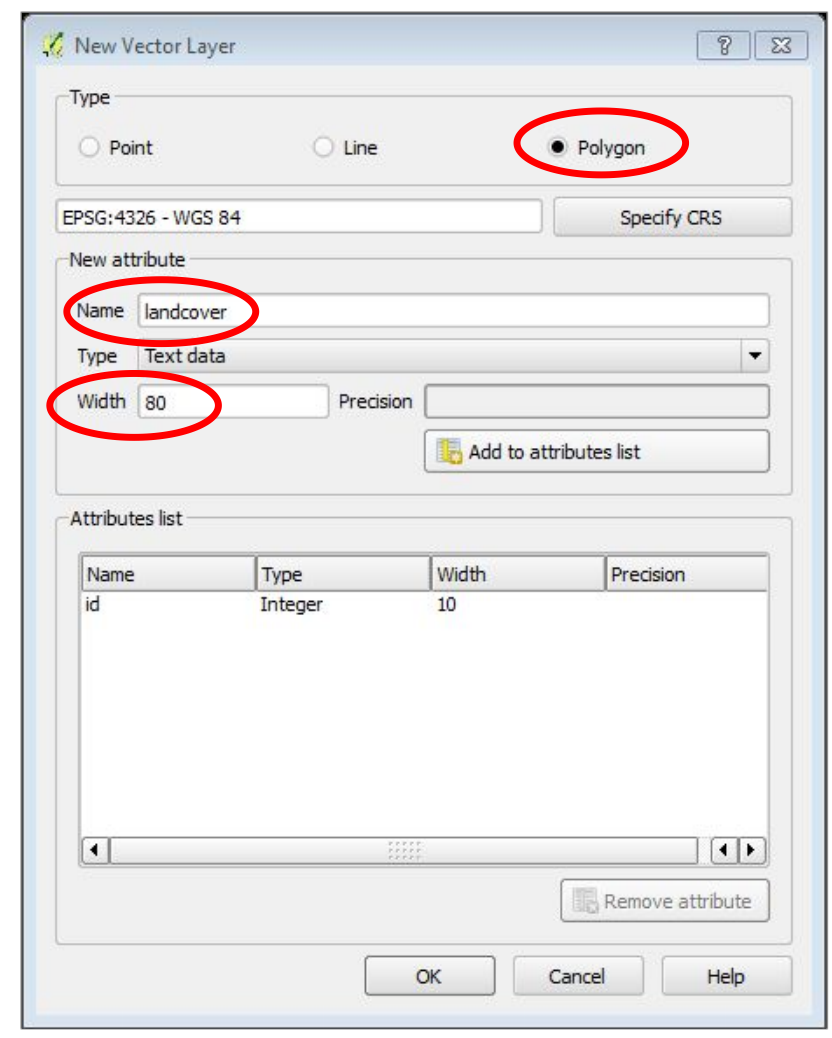

\section{Contoh soal latihan dan tugas}

1. Buat masing-masing point, line dan polygon kemudian simpan hasilnya 


\section{LAYOUT PETA}

Setelah memiliki layer-layer hasil digitasi, atau hasil olah data lainnya, selanjutnya akan melakukan proses layout peta untuk kemudian dicetak. Ada beberapa hal penting untuk diingat sebelum anda menyusun peta. Diantaranya adalah fungsi dan tujuan pembuatan peta, serta elemen atau komponen dalam peta.

Untuk membuat layout peta yang baik, perlu dipahami bahwa fungsi dari pembuatan peta adalah : (1) Menunjukkan posisi atau lokasi suatu tempat di permukaan bumi, (2) Memperlihatkan ukuran dan arah suatu tempat di permukaan bumi, (3) Menggambar bentuk-bentuk permukaan bumi. (4) Membantu mengetahui kondisi suatu daerah, (5) Menyajikan data potensi suatu wilayah, (6) Sebagai alat analisis, (7) Alat untuk mempelajari fenomena geografi di permukaan bumi.

Sedangkan tujuan pembuatan peta antara lain adalah; (1) Untuk komunikasi informasi ruang, (2) Untuk menyimpan informasi, (3) Digunakan untuk membantu pekerjaan tertentu, (4) Untuk analisis data spasial.

Selain fungsi dan tujuan pembuatan peta, Komponen atau elemen peta merupakan substansi penting yang harus ada dalam peta. Elemen-elemen dalam sebuah peta harus menarik (design yang bagus) serta informatif (menampilkan informasi sesuai tujuannya). Elemen-elemen peta yang membuat layout peta menjadi menarik dan informatif (Peterson, 2009) adalah sebagai berikut :

1. Elemen Primer ;
a. judul
b. sub judul
c. legenda
d. isi peta
e. orientasi (penunjuk arah)
f. tanggal pembuatan peta
g. penyusun peta
h. skala
I. pembatas peta (page border)

2. Elemen Sekunder ;
a. garis
b. garis koordinat
C. disclaimers 

d. sumber data
e. sitasi data
f. logo
g. grafik
h. nomer peta
I. tabel
j. hak cipta
k. sistem proyeksi
I. inset
m. deskriptif text

Dari beberapa elemen peta menurut Peterson, secara sederhana dapat ditarik kesimpulan berdasarkan layout peta secara umum, elemen dalam sebuah peta dapat anda sederhanakan sesuai dengan tujuan dari pembuatan peta tersebut, atau kepada siapa peta tersebut diperuntukkan. Tidak perlu semua elemen tersebut harus anda tampilkan dalam layout peta anda.

Beberapa elemen peta yang utama adalah sebagai berikut :

1. Isi peta ; bagian utama pada layout peta yang berisi informasi yang ingin disampaikan/ditampilkan

2. Judul peta ; deskripsi singkat mengenai isi peta, harus menggambarkan isi/informasi peta

3. Skala ; perbandingan jarak pada peta terhadap jarak sesungguhnya di lapangan

4. Legenda ; keterangan dari simbol-simbol yang digunakan pada peta

5. Orientasi ; menunjukkan arah utara

6. Garis koordinat ; memudahkan untuk melihat posisi/lokasi daerah pemetaan di permukaan bumi

7. Inzet ; menunjukkan lokasi yang dipetakan pada konteks yang lebih luas, sangat penting terutama apabila peta ditujukan kepada orang yang belum familiar dengan daerah yang dipetakan

8. Sumber peta ; referensi, bahan-bahan yang diacu dalam menyusun/membuat peta.

Peta yang baik adalah peta yang dibuat dengan mengikuti kaidah kartografis sehingga informasi yang terkandung pada peta tersebut dapat dipahami, dimengerti, dan dinikmati oleh pengguna sesuai dengan tujuan pembuatan peta. Oleh karena itu tidak perlu semua elemen seperti yang disebutkan dalam Peterson (2009) anda masukkan ke dalam layout peta. 
Melayout peta pada QGIS tidak terlalu sulit apabila sudah terbiasa melayout peta dengan software pemetaan yang lain. Anda hanya membutuhkan sedikit waktu untuk mengenali dimana bagian-bagian untuk menampilkan elemen-elemen peta. Berikut akan dijelaskan langkah-langkah penyusunan layout peta secara sederhana dalam QGIS :

1. Persiapkan dulu tampilan peta yang anda ingin buat layoutnya. Buka dan tampilkan file (.shp) boalemo_kab dan kota

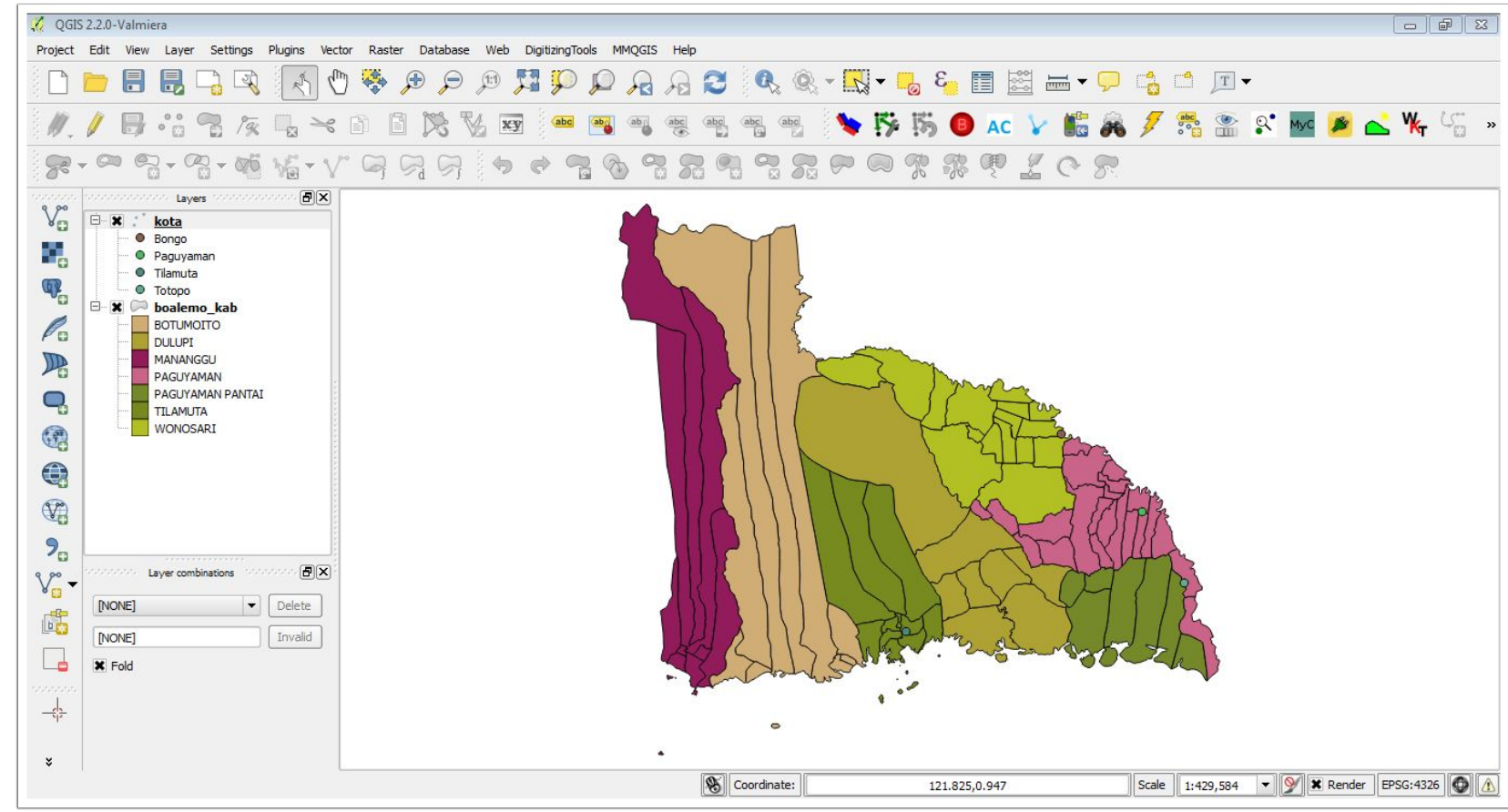

2. Klik Project --> New Print Composer atau tekan Ctrl+P. isikan namanya OK

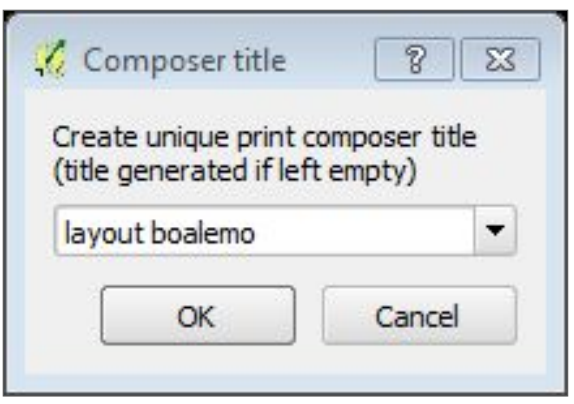


3. Maka akan muncul jendela layout boalemo

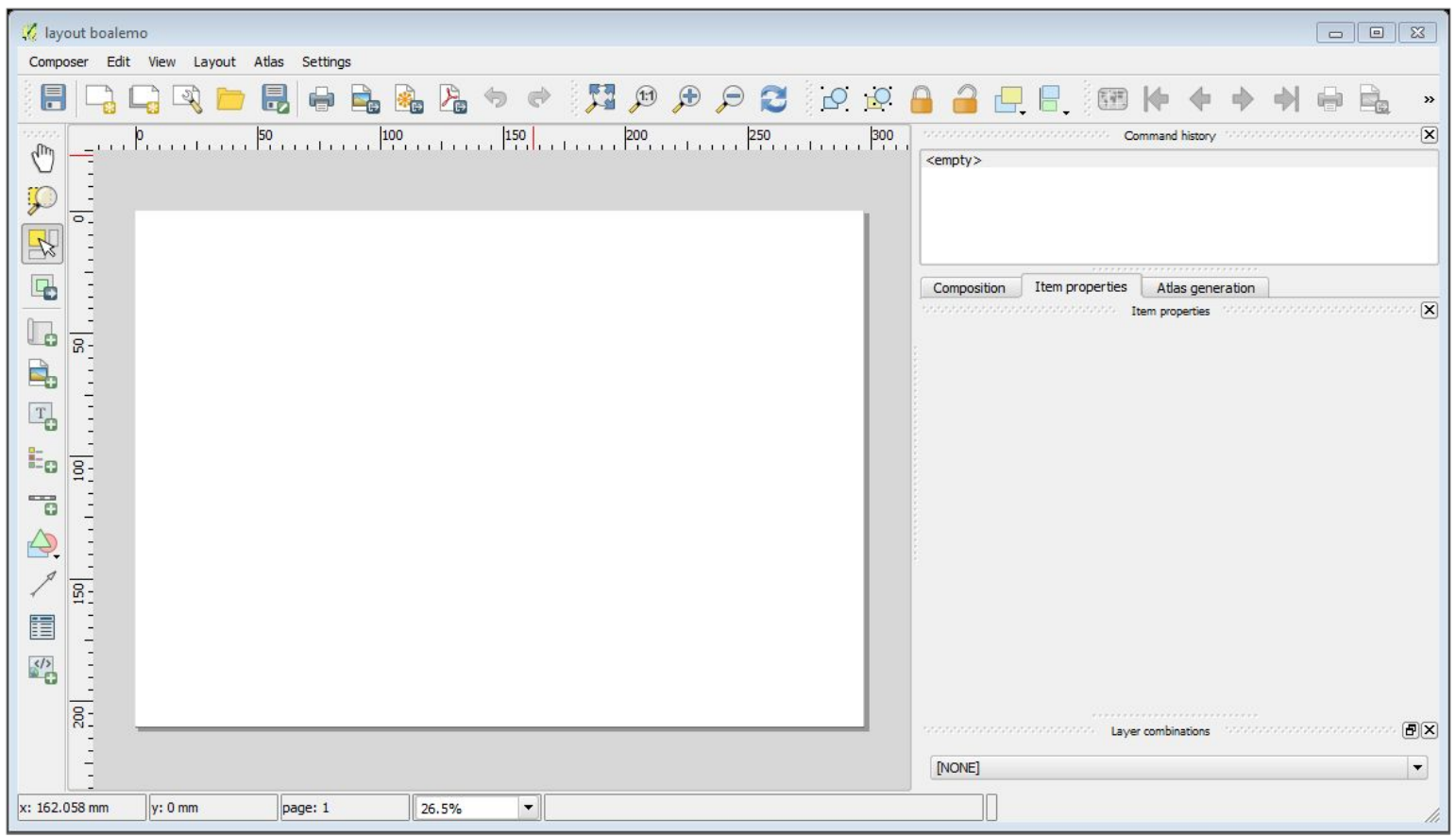

4. Untuk memulai layout klik ikon "add new map" $\mid$ layout boalemo

5. Atur komponen peta yang akan anda layout melalui tab composition, item propertiess dan atlas generation disebelah kanan canvas composer. Tab item akan selalu digunakan untuk mengatur komponen-komponen dalam layout

> Pada tab composition anda dapat mengatur ukuran kertas, bentuk grid (koordinat pada tampilan peta) yang diinginkan.

> Pada tab item properties ada beberapa hal yang dapat anda atur, yaitu ;

$\rightarrow$ Map : untuk mengatur kenampakan peta, dan skala tampilan peta

$\rightarrow$ Grid : untuk mengatur grid tampilan koordinat

$\rightarrow$ Legend

$\rightarrow$ Title

$\rightarrow$ Label 


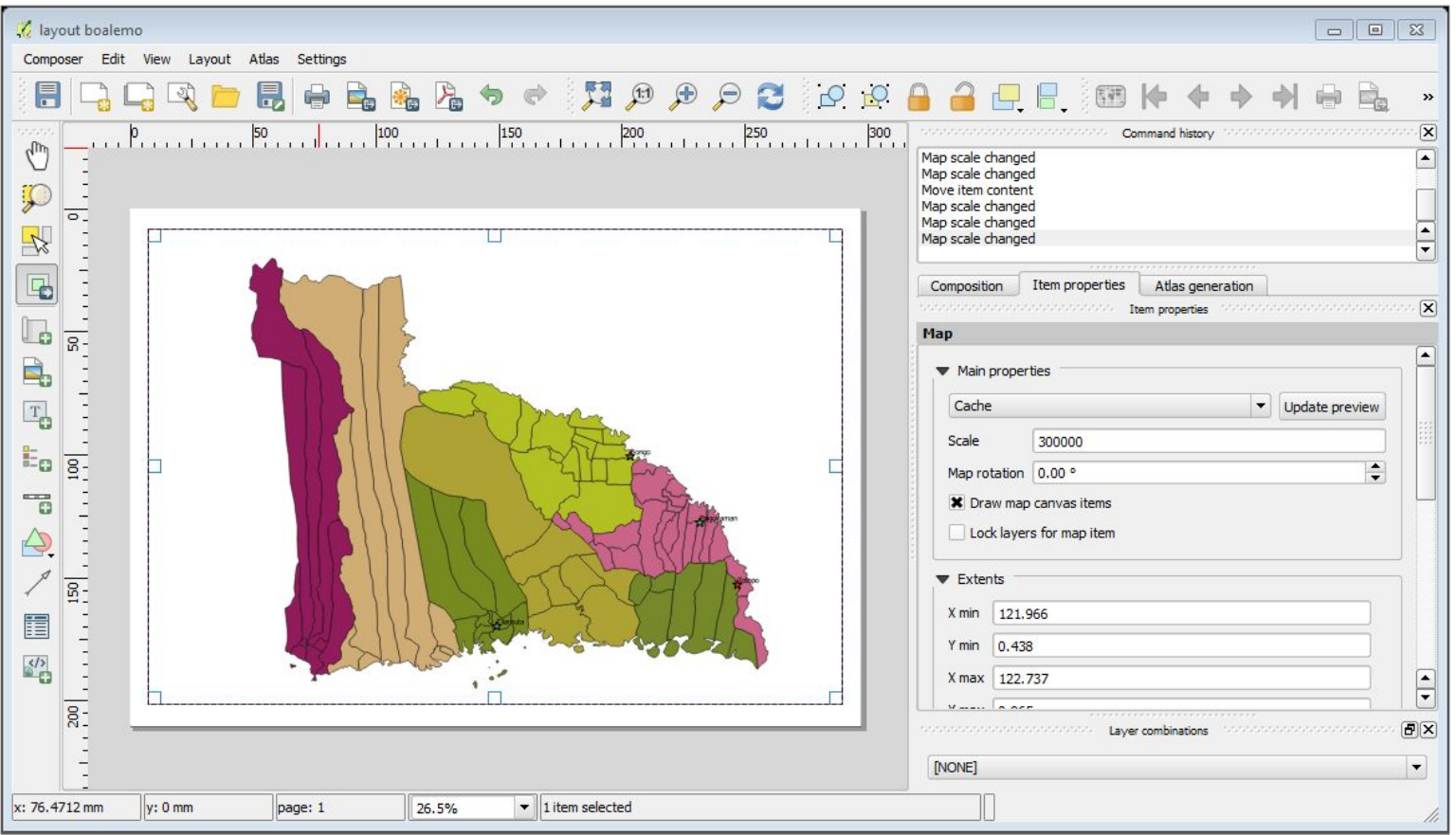

6. Kemudian tambahkan legenda pada layout peta anda dengan cara klik ikon "Add new legend" dan klik dimanapun pada bidang canvas untuk memunculkan legendanya. Anda dapat atur penempatan legenda agar tampak lebih proporsional pada peta yang susun layoutnya

7. Tambahkan skala dengan klik pada ikon "Add new scalebar", atur pada tab item, pada scale bar tab

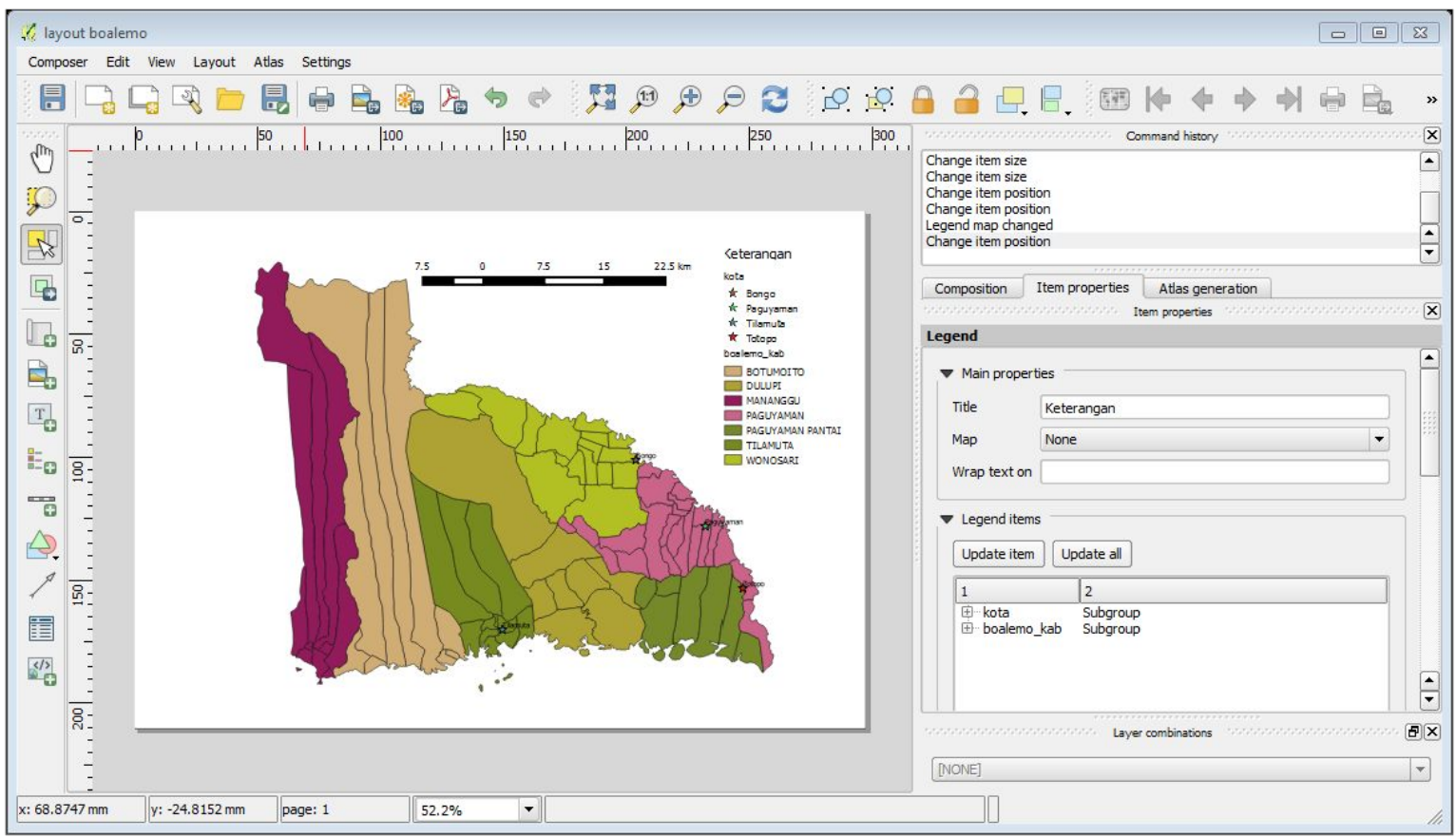


8. Untuk menambahkan orientasi pada layout anda klik pada ikon "Add Image" (anda dapat juga menambahkan gambar/foto pada layout peta anda dengan tombol ini). Setelah menunggu beberapa saat atur gambar yang ingin anda tambahkan/tampilkan pada layout

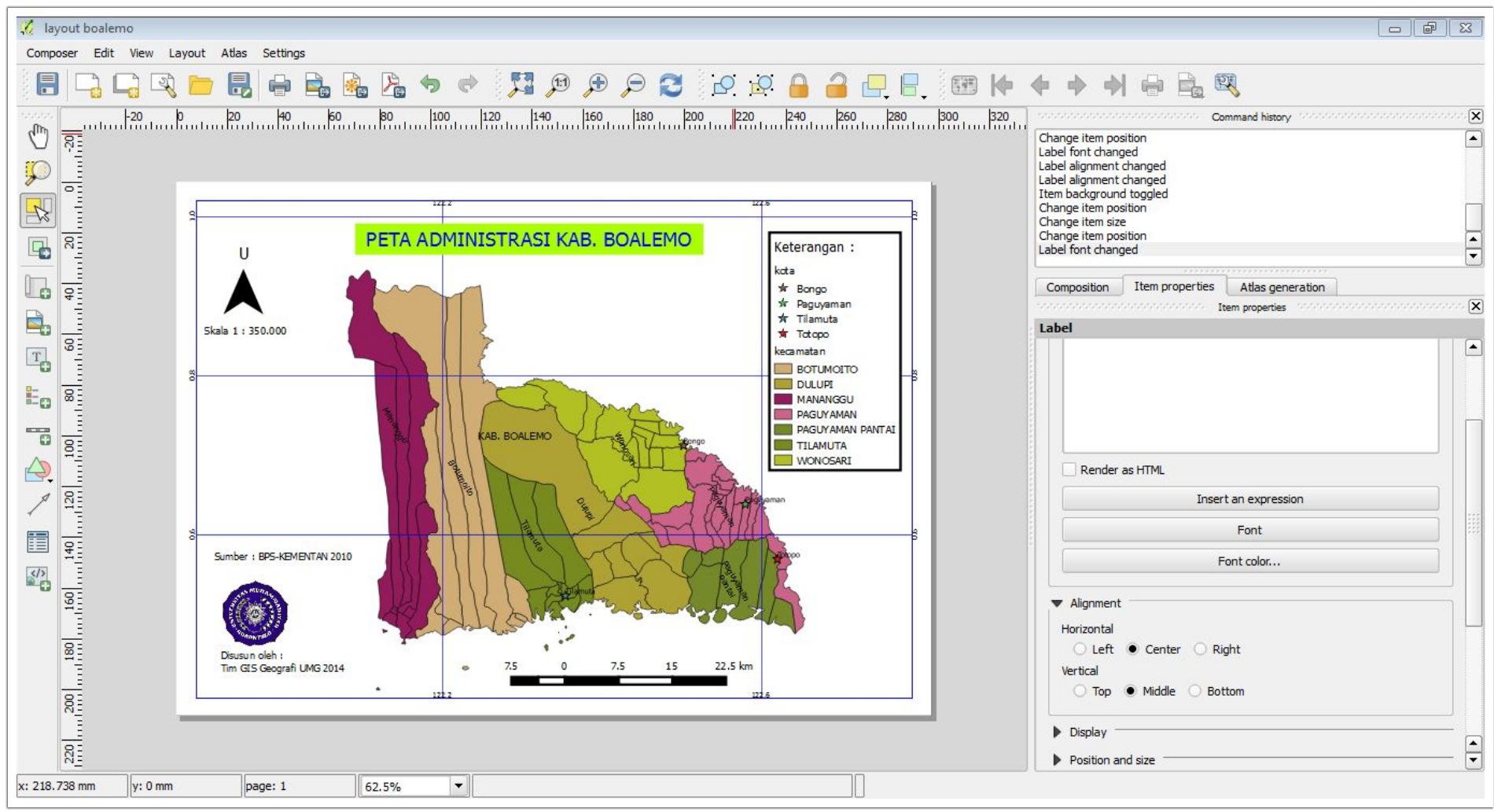

\section{Contoh soal latihan dan tugas}

1. Buatlah layout peta untuk wilayah kabupaten yang ada di Gorontalo! 


\section{Referensi :}

Nugraha, Andika Kusuma. 2009. Aplikasi open Source Quantum GIS untuk Pemetaan. Fakultas Geografi Universitas Gadjah Mada, Yogyakarta

Tutorial Quantum GIS Tingkat Dasar. 2012. Bappeda Provinsi NTB

QGIS User Guide (Rilis 2.0). 2014. QGIS Project 